\title{
Brain stimulation methods for pain treatment
}

\author{
Eugen Kvašňák ${ }^{1}$ and Richard Rokyta ${ }^{2}$ \\ ${ }^{1}$ Department of Medical Biophysics and Medical Informatics, Third Faculty of Medicine, Charles University, Prague, Czech \\ Republic \\ ${ }^{2}$ Department of Normal, Pathological and Clinical Physiology, Third Faculty of Medicine, Charles University, Prague, Czech \\ Republic
}

\begin{abstract}
Treatment of pain is one of the most important aims of medicine. Over the past several decades, invasive, semi-invasive and non-invasive brain stimulation methods have been tested and implemented for modulation of the pain. In this review, we bring an overview of those methods including stimulation of both deep brain structures utilizing invasive and semi-invasive techniques and the brain cortex stimulated by non-invasive transcranial magnetic and electrical techniques. Another potentially beneficial method that could modulate pain by stimulating the deep brain with interferential transcranial alternating current is discussed as well.
\end{abstract}

Key words: Pain - Stimulation - Transcranial - Magnetic - Electrical

\begin{abstract}
Abbreviation: AC, anterior cingulate cortex; CMPf, centromedian intralaminar perifascicular (complex); DBS, deep brain stimulation; EEG, electroencephalography; fMRI, functional magnetic resonance imaging; fNIRS, functional near red stimulation; GABA, gamma-aminobutyric acid; IC, internal capsule; if-tACS, interference transcranial alternating current stimulation; IPG, implanted pulse generator; NAc, nucleus accumbens; NIBS, non-invasive brain stimulation; PVG/PAG, periventricular and periaqueductal gray; rTMS, repetitive transcranial magnetic stimulation; $\mathrm{tCS}$, transcranial current stimulation; $\mathrm{tDCS}$, transcranial direct current stimulation; TENS, transcutaneous electrical nervous stimulation; $\mathrm{tES}$, transcranial electrical stimulation; TMS, transcranial magnetic stimulation; tPCS, transcranial pulsed current stimulation; tRNS, transcranial random noise stimulation; VPL, ventral posterolateral (nucleus); VPM, ventral posteromedial (nucleus).
\end{abstract}

\section{Introduction}

Pain as well as pain treatment methods have accompanied mankind throughout the latter stages of evolution. Early therapies for pain were first seen in China, and then in the Middle East and India. The main approach to pain treatment has been pharmacological, initially in the form of plantbased phytotherapy, with other drugs being added over time (Harrison et al. 2012; Amin and Hosseinzadeh 2015; Finch and Drummond 2015; Mehreen et al. 2016). From antiquity, through the middle ages and into the modern age,

Correspondence to: Eugen Kvašňák, Department of Medical Biophysics and Medical Informatics, Third Faculty of Medicine, Charles University, Prague, Czech Republic

E-mail: eugen.kvasnak@lf3.cuni.cz each time period was accompanied by discoveries of new painkillers. In ancient times, electric stimulation methods, using shocks from electric catfish (Malapterurus electricus), found in the Nile, were used to treat painful conditions. Even though pharmacotherapy alternatives are becoming more and more effective, pain medication will likely remain the primary method of pain treatment for the foreseeable future, however, in cases where pain is pharmaco-resistant, pharmaceutical alternatives become extremely important (Oakley 2003; Hirayama et al. 2006; Lefaucheur 2008; EkeOkoro et al. 2018).

Significant scientific study of electrical pain treatment did not really start until 1967, when Wisconsin colleagues Shealy, Mortimer, and Resnik first used electrical stimulation to treat pain (Shealy et al. 1967). Their method involved stimulation of the dorsal spinal cord fasciculi. Electro- 
therapy methods for pain after 1967 were mainly invasive, that is, electrodes are applied either to the spinal cord or to brain regions, especially the brain's motor region. Next came methods for deep brain electric stimulation (targeted on areas and paths thought to be associated with pain initiation) and other non-invasive methods, such as stimulation via peripheral, transcutaneous nervous electrical stimulation (TENS), which was one of the first methods developed, and is still used successfully today (Dailey et al. 2013; Rakel et al. 2014; Hazime et al. 2015; Johnson et al. 2017). Since 1997, more non-invasive methods have emerged, notably non-invasive transcranial magnetic stimulation, which is initiated by a magnetic field that is then transformed into an electric field in the brain. This stimulation does not penetrate deeply into the brain, nonetheless the methods are effective in activating areas of the cerebral cortex, and when using today's most modern treatments, can activate areas in the embedded cortex, i.e., the insula (D'Agata et al. 2015). Non-invasive stimulation also uses direct current stimulation (tDCS) methods, and recently, there has been intense experimentation with other methods such as transcranial alternating current (tACS) and transcranial random noise (tRNS) stimulation (Curatolo et al. 2017; O'Connell et al. 2018).

Pain is defined as physical suffering resulting from an injury or disease, experienced through the central nervous system. Pain is a complex phenomenon that is not yet fully understood. Its purpose is to alert the body to damage or danger to its tissues, although scientists do not fully understand what determines the levels and intensity of pain experienced by people. Short-lasting pain that triggers an immediate physical response is known as acute pain (Radnovich et al. 2014). Long-lasting severe pain that persists without diminishment over long periods is known as chronic pain (Crofford 2015a). Additionally, there is a type of pain called psychological pain (Flor 2014; Crofford 2015b). Recent research has shown that the chemicals produced by anxiety are similar to those that are released in response to physical injury. Pain is a complex behavioral paradigm that includes autonomous, neuroendocrine, emotional, and cognitive components that involve distinct neural circuits (Monticone et al. 2015; Peters 2015).

Pain signals travel through the body along billions of specialized nerve cells reserved specifically for transmitting pain messages. These cells are known as nociceptors (Serra et al. 2014). Chemical neurotransmitters that can initiate a pain signal include prostaglandins, bradykinin, and the most potent painful substance known to humans, a chemical known as substance P (the P stands for pain). Prostaglandins are ubiquitous and are manufactured from fatty acids in nearly every tissue of the body (Ma and Eisenach 2002; Schaible et al. 2011). Analgesic pain relievers, such as aspirin and ibuprofen, work by inhibiting prostaglandin production.

After an injury, cells near the trauma site release the abovementioned chemicals, which activate nociceptors leading to the central nervous system. The pain signal enters the spinal cord via the dorsal root, where it synapses (via interneurons in the dorsal horn) with motor neurons that trigger contraction of the specific muscles needed to pull the injured part of the body away from the source of pain. Additional nociceptors that synapse in the dorsal horn send the signal towards the brain, where they are first processed by the thalamus and then passed to the cerebral cortex (Obara et al. 2013). Here, the brain fully processes the information, locates its source in/on the body, and begins sending signals to relieve the pain (Basbaum et al. 2009).

As the pain signals travel up the spinal cord towards the brain, they are sorted according to severity. The body has two distinct pathways for transmitting pain messages, i.e., epicritic and protopathic. The epicritic system is used to transmit messages of sudden, intense pain, such as that caused by cuts or burns (Bigley 1990). The neurons that transmit such messages are called A fibers, and are capable of transmitting signals very quickly. The protopathic system, which transmits signals over $C$ fibers, is used to transmit less severe pain signals, such as one might experience after strenuous exercise. The $\mathrm{C}$ fibers of the protopathic system transmit signals more slowly than the A fibers of the epicritic system (Reddi 1998; Serpell 2006).

The gate theory of pain holds that the nervous system can only process limited amounts of information at a time (Melzack and Wall 1965). This may explain why chronic pain presents its own set of problems. Treating chronic pain is difficult because the pain damages the central nervous system, making it weaker and more susceptible to pain. Similar problems also arise when nerve cells are damaged by chemotherapy, diabetes, shingles, or other diseases. In the case of arthritis and other inflammatory diseases, the body's threshold for pain is lowered, thus producing more pain from fewer pain signals (Andersen et al. 2014; Babatunde et al. 2018; Gijon-Nogueron et al. 2018).

Treatments for pain vary widely. For mild pain, the most common form of treatment is aspirin, a medication discovered in the 19th century and derived from salicin, a chemical found in the bark of the willow tree (Walker et al. 2018). Today, there are several mild painkillers on the market for the relief of minor, inflammatory pain, including ibuprofen and acetaminophen. (Moore et al. 2015). For more severe pain, opiates, which are derived from the opium poppy, a common flowering plant, are often used (Pergolizzi et al. 2008; Wolff et al. 2012). Opiates work by attaching themselves, at the molecular level, to nerve cells that transmit pain signals. Opiates work very well in relieving pain but are quite dangerous and can become addictive. 
In the 1970s, scientists began looking for natural opiate-like substances, and found that the body does indeed produce its own painkillers, which have come to be called endogenous opioids. The two most common endogenous opioids are endorphins and enkephalins. These chemicals attach themselves to opiate receptors on nerve cells just as opiates do. Studies have found that the body can be stimulated to release these chemicals using TENS and acupuncture (Levine and Taiwo 1989; Stein et al. 1990; Kalra et al. 2001; Stein et al. 2003; Ibrahim et al. 2005; Ainsworth et al. 2006; Sabino et al. 2008).

\section{Deep brain structures in pain treatment}

Deep brain structures became a target for pain treatment several decades ago. They are usually activated by electric current stimulating the cerebral motor cortex, which orthodromically stimulates the thalamus. The thalamus is full of gamma-aminobutyric acid (GABA) receptors and produces large amounts of GABA, which influences the ascending thalamo-cortical pathway that leads from the thalamic nuclei (in particular the ventral posterolateral (VPL) and ventral posteromedial (VPM) nucleus to the postcentral gyrus of the cerebral cortex, which is located in Brodmann's Areas 3, 2 , and 1 (areas of pain perception). Despite the demand for both safe and easy to use methods for stimulation of deep brain structures, contemporary methods for stimulation of deep brain structures are either effectively strong but invasive or they are non-invasive but ineffectively weak. The inspiration for a potential solution to this problem, i.e., effective but non-invasive stimulation of deep brain structures comes from tACS, which has been previously used experimentally

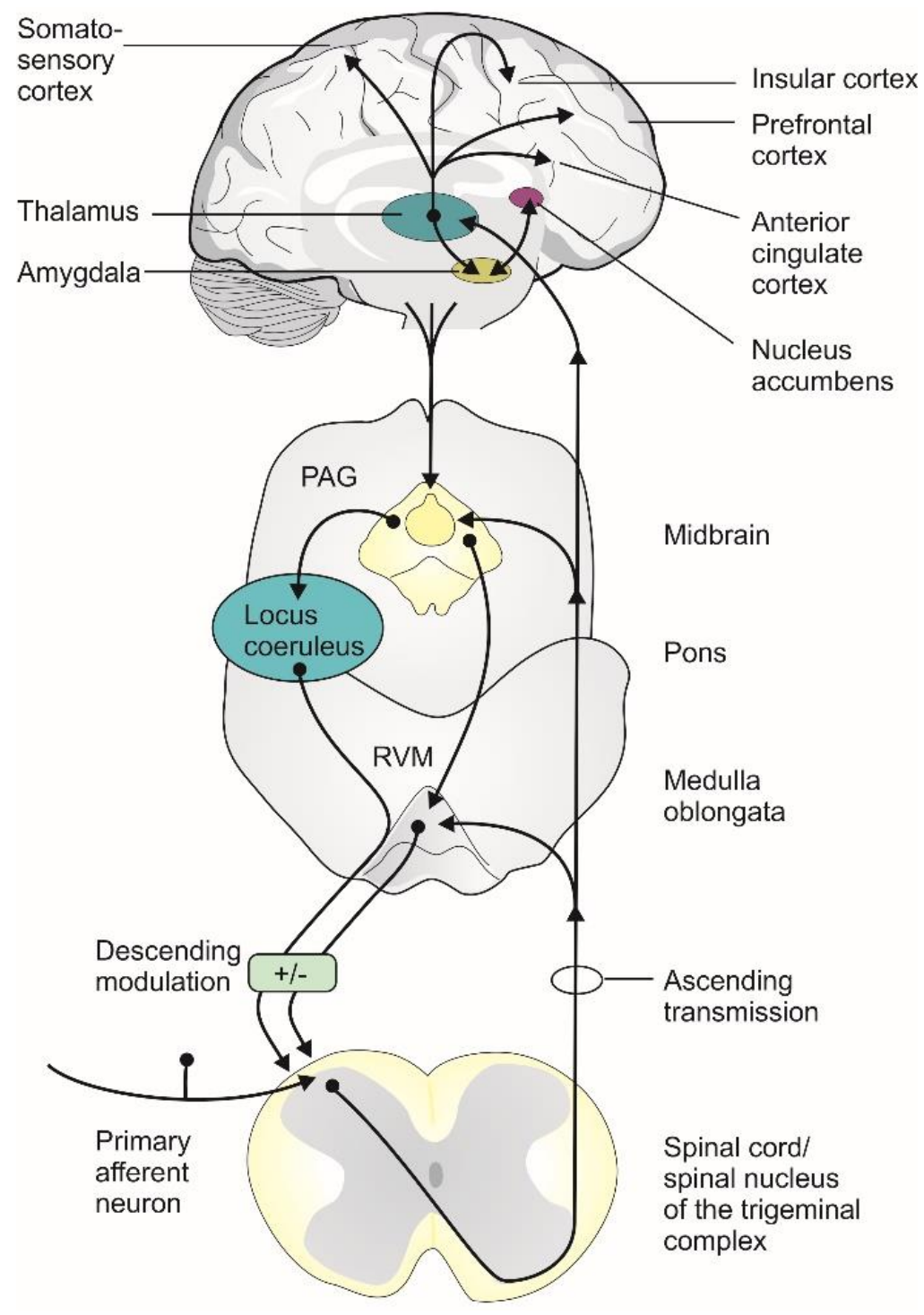

Figure 1. Pathways and brain regions involved in the transmission and modulation of pain signals. Primary afferent neurons, with their cell bodies in the dorsal root ganglia, or trigeminal ganglion (mouth and face), couple with second order neurons in the dorsal horn of the spinal cord, or the spinal nucleus of the trigeminal complex. Axons of the second order neurons cross the midline and project to the thalamus and a variety of other targets in the medulla oblongata, pons, and mid brain, including the rostral ventral medulla (RVM) and the periaqueductal gray (PAG). Third order neurons, with their cell bodies in the thalamus, project to the somatosensory cortex, responsible for the sensory-discriminative aspects (intensity, location and quality) of pain, and to the limbic cortical areas, such as the anterior cingulate, insula, and the prefrontal cortex, which are involved in mediation of the affective / emotional components (aversiveness) of pain. Thalamic neurons also project to the amygdala, which in turn interact with the nucleus accumbens, a region involved in both pain processing and the mediation of reward / motivational behavior. These various brain regions also send input to the PAG, which, via the raphe nuclei in the RVM and the locus coeruleus, send descending pain modulatory projections back to the first synapses in the afferent pathways. (This figure was courteously provided by its author Prof. Ernst Brodin, by the Tidende Journal which the figure published and by illustrator Sole Lätti). 
in different setups in an effort to therapeutically influence pain (Angelakis et al. 2013; Bae and Lee 2014; Elnaggar and Elshafey 2016; Gundlach et al. 2016; Hasegawa at al. 2016; Peng and Tang 2016; Albornoz-Cabello et al. 2017; Franco et al. 2017; Ladi-Seyedian et al. 2017). Exploring the capability and suitability of tACS for pain modulation or suppression are tasks for the future.

\section{The analgesic effects of stimulating deep brain structures}

The analgesic effects of stimulating deep brain structures (for involved structures see Figure 1) have been known for more than a half-century and date back to experiments by Olds and Milner (1954). Since its first use, deep brain stimulation (DBS) has been tested on several types of pain (e.g., chronic pharmaco-resistant orofacial pain, rheumatoid arthritis pain, etc.). Additionally, targets for DBS have also been investigated and include: the internal capsule (IC) (Adam et al. 1974), thalamic structures such as the somatosensory intralaminar thalamus (nucleus centro medianus, centromedian intralaminar perifascicular complex, CMPf) (Hécaen et al. 1949), periventricular and periaqueductal gray (PVG/PAG) (Duncan et al. 1991), nucleus accumbens (NAc) (Mallory et al. 2012), and the anterior cingulate cortex (AC) (Antal et al. 2014; Boccard et al. 2014).

\section{Anterior cingulate stimulation}

Anterior cingulate (AC) stimulation in patients with chronic pain with a range of etiologies (failed back surgery syndrome, post stroke pain, brachial plexus injury, cervical spinal cord injury, head injury, and pain of unknown origin, etc.) has resulted in improvement that was also associated with improved subjective analgesic properties relative to PVG stimulation alone (Boccard et al. 2014). Additionally, there was a comprehensive review (Russo and Sheth 2015) of preclinical and clinical studies of AC stimulation as part of pain treatment.

\section{Nucleus accumbens}

The nucleus accumbens (NAc) forms an extension of the ventral striatum, which is involved in reward processing. DBS of the NAc has been used to treat depression and obsessive-compulsive disorder (Hauptman et al. 2008; Franzini et al. 2010). NAc also sends inhibitory projections into the medial thalamus (Albe-Fessard et al. 1985) and from there to the dorsal horn neurons, which modulate pain perception (Lorenz et al. 2003). The NAc, together with the prefrontal cortex, insula, and AC have been shown to mediate the affective component of pain (Albe-Fessard et al. 1985; Lorenz et al. 2003). There was also a case of post-stoke pain that was treated, with great effect, using DBS targeted on the NAc and PVG simultaneously (Mallory et al. 2012).

\section{Somatosensory thalamus}

The somatosensory thalamus, consisting of the ventroposterior lateral (VPL) and ventro-posterior medial (VPM) nuclei, has, in the past, been targeted for stimulation to suppress aberrant neuronal firing, which was observed in chronic pain (Gerhart et al. 1983); presumably driven by the absence of normal sensory input (Mazars et al. 1973). The now obsolete gate control theory (Melzack and Wall 1965) postulated that low threshold somatosensory pathways inhibit pain perception and that stimulation of this pathway would reduce neuropathic pain. This idea has been supported using animal models in which VPL stimulation inhibited spinothalamic nociceptive neurons (Gerhart et al. 1983) as well as in modulation of facial anesthesia dolorosa (Hosobuchi et al. 1973), inhibition of the ipsilateral or contralateral VPL (Gerhart et al. 1983), neuropathic pain secondary to brachial plexus injuries, and phantom limb pain (Pereira et al. 2007, 2013).

\section{The peri-ventricular and periaqueductal gray}

The peri-ventricular and periaqueductal gray (PVG/PAG) is the most promising target for DBS in the treatment of chronic pain (Bittar et al. 2005). The first descriptions of DBS of human PVG/PAG demonstrated relief of somatoform and nociceptive pain in both acute and chronic settings (Richardson and Akil 1977a, 1977b). This was consistent with descriptions of the PAG-derived descending inhibitory system modulating nociceptive inputs at the spinal level (Mayer and Liebeskind 1974). Recent evidence demonstrates PAG DBS causes a focal reduction of opioid binding in areas of electrostimulation, which is consistent with the release of endogenous opioid peptides (Sims-Williams et al. 2017). The centromedian parafascicular complex (CMPf) has afferents from the ventral posterolateral thalamus (VPL), spinothalamic tract (STT), and trigeminal lemniscus, and efferents to the striatum, cortex, and AC. The CMPf is responsive to noxious stimuli and sensitive to stimulus intensity but its stimulation has yielded inconsistent results (Davis et al. 1998; Weigel and Krauss 2004). Neuropathic pain in humans corresponds with increased activity of CMPf neurons (Hirato et al. 1991). CMPf stimulation or ablation has been found to be helpful in the treatment of central pain and deafferentation pain (Hariz and Bergenheim 1995; Hollingworth et al. 2017).

\section{Invasive brain stimulation}

Invasive brain stimulation methods, in general, involve situations in which brain structures are in physical contact ("in situ") with the stimulating microelectrode. In practice it means stimulation of the superficial (cortex) or deep brain structures, which are out of reach of non-invasive stimula- 
tion. DBS is a minimally invasive, targeted neurosurgical intervention that enables structures deep in the brain to be stimulated electrically using implanted electrodes and a pacemaker (see Figure 2). The method was initially developed for and applied to movement disorders in several target areas; such as the thalamus, the pallidum, and the subthalamic nucleus. It is currently being extended to other indications, such as epilepsy (Chan et al. 2018; Hartl et al. 2018; Lobato-Polo et al. 2018; Son et al. 2018), dystonia (Magown et al. 2018; Takeda et al. 2018), tremor (Moldovan et al. 2017; Camalier et al. 2018), cluster headache (Chabardès et al. 2016; Láinez and Guillamón 2017), chronic pain, including pain from stroke (Lempka et al. 2017; Gopalakrishnan et al. 2018), amputation (Pereira et al. 2013; Kuffler 2018), trigeminal neuralgia (Nizard et al. 2012; Yamgoue et al. 2016) and multiple sclerosis (Abboud et al. 2017; Oliveria et al. 2017), and recently to psychiatric disorders, such as obsessive compulsive disorder (Naesström et al. 2017; Winter et al. 2017; Franzini et al. 2018), Tourette's syndrome (Marceglia et al. 2017; Martinez-Ramirez et al. 2018), and depression (Kringelbach et al. 2007b). The mechanism of action will likely turn out to be quite complex, involving cell-firing inhibition, neurotransmitter depletion, jamming and excitation of inhibitory pathways that lead to functional inhibition, and mimicking the effects of lesioning of the stimulated structures (Benabid 2014).

While DBS for Parkinson's disease is based on 20 years of experience, a standard and widely accepted DBS treatment for chronic pain (even though DBS has been used to treat pain for over 50 years) remains restricted to a handful of experienced, specialist centers (Pereira et al. 2013).

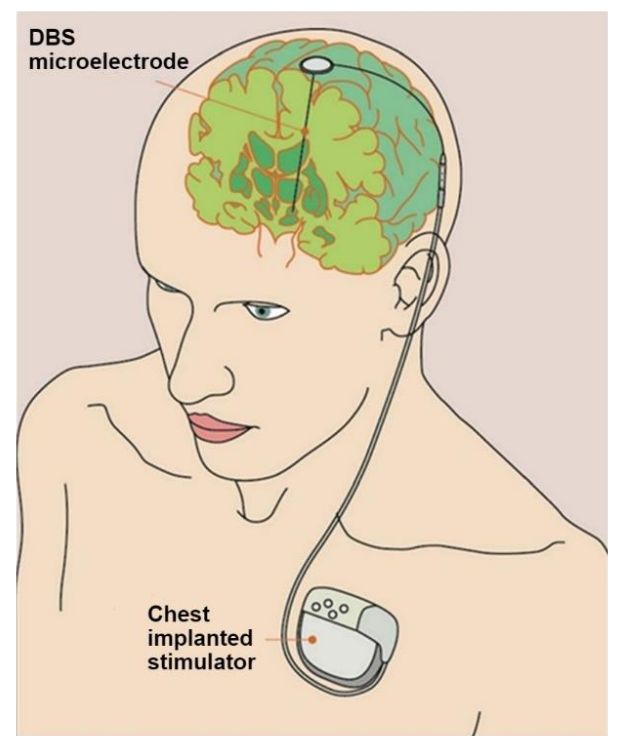

Figure 2. Arrangement of deep brain stimulation (DBS) technique.

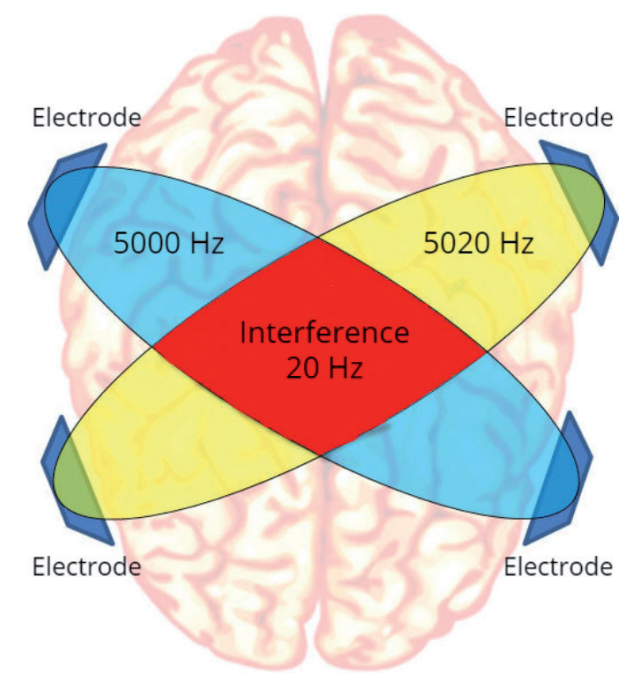

Figure 3. Scheme of interferential transcranial alternating current stimulation (if-tACS) with potential use to modulate pain associated with deep brain structures. In principle, if-tACS is to produce low frequency effects at sufficient intensity and depth to avoid patient discomfort in the superficial tissues (i.e., the skin). Two AC currents with sligthly different frequencies are used in crossed arrangement. The result frequency affecting tissue in the crossed section (in deep structures) is equal to the difference between original AC frequencies. For more details, see text.

The DBS system consists of three components: an implanted pulse generator (IPG), leads, and an extension. The IPG is a battery-powered neurostimulator, encased in a titanium housing that sends electrical pulses to the brain that interfere with neural activity at the target site. The lead is a coiled wire, insulated with polyurethane, with four platinum-iridium electrodes that are placed in one or two different nuclei of the brain. The lead is connected to the IPG by an extension, which is insulated wire that runs below the skin, from the head, down the side of the neck, behind the ear, to the IPG, which is placed subcutaneously below the clavicle, or in some cases, the abdomen. The IPG can be calibrated to optimize symptom suppression and control side effects. DBS lead placement is done relative to the type of symptoms to be addressed. For non-Parkinsonian essential tremor, the lead is placed in either the ventral intermediate nucleus of the thalamus or the zona incerta (Holslag 2018); for dystonia and symptoms associated with Parkinson disease, the lead can be placed in either the globus pallidus internus or the subthalamic nucleus. The leads are placed in the NAc for obsessive compulsive disorder and depression, the posterior thalamic region or periaqueductal gray for incessant pain, and in the anterior thalamic nucleus for epilepsy. All three components of the system are surgically implanted inside the body. Lead implantation can take place under local or general anesthesia 
("asleep DBS"). A hole about $14 \mathrm{~mm}$ in diameter is drilled in the skull and the probe electrode is inserted stereotactically. During the procedure, when using local anesthesia, feedback from the patient is used to determine optimal placement of the permanent electrode. The generator is programmed to send continuous electrical pulses via the electrodes to the brain at specific frequencies. Pulse amplitudes can go up to $4 \mathrm{~V}$, with frequencies of $10-150 \mathrm{~Hz}$ and widths $0.1-0.5 \mathrm{~ms}$ depending on the disease being treated.

In chronic pain, DBS is targeted on the periaqueductal gray, while the periventricular gray is targeted in nociceptive pain; for neuropathic pain the target is the internal capsule, ventral posterolateral nucleus, and the ventral posteromedial nucleus (Johnson et al. 2008). DBS has also been used for phantom limb pain (Kringelbach et al. 2007a).

\section{Semi-invasive brain stimulation}

Semi-invasive brain stimulation methods, contrary to the DBS methods, do not need a permanently implanted wire or optical fiber. They need just nanoparticles incorporated into neural tissue and activated by an external non-invasive stimulus. Thus, cellular signaling deep inside the brain can be controlled remotely without permanent implants. In this context, the term "semi-invasive" is related to how nanoparticles are introduced into the body. In general, it can be injection, ingestion, and inhalation or via skin or wounds; currently, injection is only used for experimentation.

Protocols for nanomaterial-enabled neural stimulation differ according to the site where the nanoparticles are finally distributed, and what kind of primary and secondary stimuli are utilized. The nanomaterials can be dispersed or immobilized in the extracellular environment, attached to the membrane, bound to ion channels or internalized into the cytoplasm (Wang and Guo 2016). Then, a wirelessly (non-invasively) transmitted primary stimulus (light, magnetic fields or ultrasound) penetrates through the tissues and is converted by the nanomaterial into a localized secondary stimulus, primarily electric fields or heat, at the nanomaterial-neuron interface, to stimulate the neuron (Wang and Guo 2016). Depending on to the primary and secondary stimuli, nanomaterial-enabled neural stimulation techniques can be classified into opto-electric stimulation (Lugo et al. 2012), opto-thermal stimulation (Eom et al. 2014), magneto-electric stimulation (Yue et al. 2012), magneto-thermal stimulation (Huang et al. 2010), and acousto-electric stimulation (Ciofani et al. 2010). The main benefits of nanomaterial-enabled neural stimulation technique are the significant improvement of spatial resolution and that nanomaterials can be surface-modified and bioconjugated for cell-specific targeting, can be delivered by injection, and can be matched to the dimensions of subcel- lular components, such as those of the neuronal membrane and ion channels (Winter et al. 2005; Lugo et al. 2012). For example, wireless magneto-thermal deep brain stimulation, developed and tested on mice (Chen et al. 2015), works through heat-sensitive capsaicin receptors in nerve cells and the injection of magnetic nanoparticles into specific brain regions (nanoparticles heated by external alternating magnetic fields activate ion channel-expressing neurons).

Even those semi-invasive brain stimulation methods are not used for pain treatment yet; there is no principal obstacle to doing that.

\section{Non-invasive brain stimulation}

New technological developments in non-invasive brain stimulation (NIBS) have boosted research in the fields of both therapeutic and neuroimaging. The growing use of NIBS in basic research and in clinical applications reflects its capabilities to modulate brain function in ways not feasible with other techniques. NIBS have continuously provided innovative insights into the functional relevance and plasticity of brain networks.

Experiments using an electro-magnetic field to influence disease processes have been reported many times over the last fifty years. Ziskin and colleagues (Radzievsky et al. 2004; Ziskin 2013) successfully demonstrated that local exposure of skin to low intensity millimeter-length waves caused the release of endogenous opioids, and the transport of these agents by the blood to all parts of the body resulted in pain relief and other beneficial effects.

Relative to the underlying physical principle, NIBS is based on transcranial stimulation either by magnetic field or by electric current. Both transcranial magnetic stimulation (TMS, which includes repetitive TMS, rTMS) and transcranial electrical stimulation (tES, sometimes called transcranial current stimulation, tCS) are utilized in neuroscience and clinical research, as well as in the diagnosis and treatment of neuropsychological disorders. TMS and tES can also be combined with EEG, fMRI, fNIRS, or guided navigation to improve clinical outcomes.

Transcranial stimulation using electromagnetic fields is used to modulate neuronal activity of the brain by applying external electric and magnetic fields to the surface of the scalp. Fields act on the tissues non-invasively up to a distance of a few centimeters below the surface of the skull; thus, the fields can reach the gyri of the cortex and to a more limited extent the sulci in between the gyri. Fields affect brain tissue by inducing depolarization or hyperpolarization of neuronal membranes, which is accompanied by a change in neuron excitability; when used at sufficiently high intensities, it can also lead to action potentials.

From a physiological point of view, TMS activates axons via short-pulsed stimulation that leads to new action potentials, whereas tES has the potential to manipulate the 
membrane potential of neurons and modulate spontaneous firing rates, but is insufficient, on its own, to induce action potentials in resting neurons. Despite the very different modes of action between TMS and tES, prolonged application of either technique can cause changes in the excitability of neurons and networks that outlast the actual stimulus application by minutes or even hours.

Both techniques produce a combination of excitatory and inhibitory effects at the neuronal level. The polarization of neurons is changed and, depending on the stimulation parameters, regional cortical excitability either increases or decreases. Many different stimulation protocols have been developed over the years and it is common practice to label protocols as either inhibitory or excitatory. Even so, the effects on cortical excitability continue to be investigated with the goal of defining protocols as definitively inducing neuro-enhancement or neuro-plasticity within a specified neuronal population; frankly, there is still a long way to go. On the other hand, there are certain NIBS protocols that have become well established.

Whether there will be enhanced or impaired effects at the perceptual, cognitive, or behavioral level depends not only on excitability changes but also on the functional properties and underlying mechanisms of all brain areas involved, as well as the interactions between them. This is exactly why both neuro-disruptive and neuro-enhancement effects are scientifically valuable, i.e., in the proper theoretical framework, they allow us to begin teasing apart the affected functional neuronal architecture (Duecker et al. 2014).

Despite the current level of knowledge, many questions about the mechanisms of neuromodulation via NIBS remain open. There are basic physical facts, for instance, everyone agrees that NIBS affects neural activity and ultimately behavior through the generation of electric fields and the associated electric currents (Basser and Roth 2000; Wagner et al. 2007) or via magnetic fields (Oliviero et al. 2011), so it makes sense to refer to NIBS as having an electric component and a magnetic component. The biologic effects of all transcranial electromagnetic stimulation techniques are mediated by exogenously generated electromagnetic fields. It is the spatial and temporal field characteristics that distinguish each stimulation modality. The problem of how transcranial electromagnetic stimulation affects brain function is generally parsed into a consideration of the characteristics of the electromagnetic fields generated in the brain during stimulation and how the fields modulate brain function to ultimately effect cognitive/behavioral changes (Hallett 2007; Peterchev et al. 2012).

\section{NIBS: transcranial magnetic stimulation}

In transcranial magnetic stimulation (TMS), the magnetic field is produced by passing a strong current through an electromagnetic coil placed on the scalp, which in turn induces an electric field and eddy-currents in the underlying cortical tissue, where it produces localized axonal depolarization. TMS has become a major tool in brain research and the treatment of various psychiatric and neurological disorders such as depression, schizophrenia, Parkinson's disease, Alzheimer's disease, and various addictions (McNamara et al. 2001; Ferreri et al. 2003; Fregni et al. 2005; George and Belmaker 2007; Politi et al. 2008; Prikryl et al. 2013; Holtzheimer and McDonald 2014; Li et al. 2013; Shen et al. 2016, 2017). However, deeper structures such as the nucleus accumbens (NAc), ventral tegmentum area (VTA), amygdala, medial prefrontal cortex, and cingulate lie too deep inside the brain $(6-7 \mathrm{~cm})$ to be reached by the magnetic fields generated through standard TMS. Deep TMS (dTMS), which uses a novel coil design suitable for direct stimulation of deeper brain regions (by significantly reducing the decay rates), has recently been demonstrated (Lu and Ueno 2017).

TMS involves administration of magnetic pulses to localized brain areas. The effects of a single TMS pulse are brief and can affect ongoing neuronal processes. Rhythmic pulse sequences, on the other hand, can yield longer-lasting effects on the human brain (Hallett 2007). The effectiveness of different frequencies of repetitive TMS (rTMS) in the treatment of orofacial pain has been tested (Rokyta and Fricova 2012; Fricová et al. 2013; Kohútová et al. 2017). Beside TMS and rTMS, low-field magnetic stimulation (LFMS) and magnetic seizure therapy (MST) are also available. Another, lesser used method, is transcranial static magnetic stimulation (tSMS), which exposes the brain to a static magnetic field by positioning a magnet on the head (Oliviero et al. 2011; Paulus 2011a). Pulsed magnetic fields have also been successfully used, to affect pain processing (Robertson et al. 2010), in the treatment of musculoskeletal chronic pain (Thomas et al. 2007), rheumatoid arthritis, and fibromyalgia (Thomas et al. 2001; Shupak et al. 2006).

\section{NIBS: transcranial electrical stimulation}

The history of transcranial electrical stimulation (tES) of the human brain is quite long. In ancient Rome, patients with unbearable head pain were sometimes treated with jolts from the electricity-producing black torpedo fish, or an electric ray. After Alessandro Volta's invention (in 1800) of the electric battery (i.e., the "voltaic pile," which was capable of producing a steady electric current), researchers began to investigate the application of direct current (DC) in a variety of neurological diseases. These early efforts were abandoned mainly because of a lack of sufficiently reliable evaluation methods.

Priori (1998) was among the first to measure the effects of direct current application on the human cortex via changes 
in evoked motor potentials. To get the electrical current to pass through brain matter, tES is applied over larger areas of the cortex compared to TMS (Paulus 2011b). tES uses a weak electric current (0.1-2 mA) applied via electrodes placed on the scalp. The current field, due to inhomogeneity and anisotropy of the skull and tissues, is inhomogeneous, which leads to variance. Most of the electric current enters the surface layers (skin, etc.) and only a small portion enters the cerebral cortex, where it affects the membrane potential of neurons.

tES is a collection of techniques that includes: tDCS, high-definition transcranial direct current stimulation (HD-tDCS), tACS, transcranial random noise stimulation (tRNS), transcranial Pulsed Current Stimulation (tPCS), cranial electrical stimulation (CES), and electro-convulsive therapy (ECT).

Safety of low intensity tES as well aws the ethical, legal, regulatory and application guidelines for tES use were reviewed recently by the $\mathrm{tES}$ scientific community at a conference in Göttingen, Germany, on September 6-7, 2016 (Antal et al. 2017).

\section{$t D C S$}

tDCS uses a uniform electric current intensity of 0.4-2 mA for 5-30 minutes and is applied across surface electrodes placed on the head. Current changes are largest directly beneath the electrodes: the area under the cathode is targeted to reduce excitability of cortical neurons and the area under the anode is targeted to have the opposite effect. By changing the surface area of the electrodes, it is possible to vary the current density and thus the effect at both electrodes. Changes can persist for several hours after application. tDCS is reliable in terms of parameters such as stimulation intensity and duration, and validation of its plastic after-effects (Nitsche and Paulus 2000, 2001; Nitsche et al. 2003, 2008). In order to achieve after-effects, stimulation needs to last for at least three minutes with an intensity of at least $0.6 \mathrm{~mA}$ (Nitsche and Paulus 2000). Not surprisingly, the direction of electrode polarization is critical in terms of the after-effects. Through stimulation of the motor cortex, tDCS can be used for: chronic pain (Deer et al. 2014; Souto et al. 2014; Hodaj et al. 2016), pain after endoscopic retrograde cholangiopancreatography (Borckardt et al. 2011), trigeminal pain including refractory orofacial pain (Antal et al. 2010; Hansen et al. 2011; DosSantos et al. 2012; Hagenacker et al. 2014; Fricova et al. 2016; Kreuzer et al. 2017), fibromyalgia (Valle et al. 2010; Cummiford et al. 2016; Castillo-Saavedra et al. 2018), major depression (Vigod et al. 2014; Tortella et al. 2015; Brunoni et al. 2016; Liu et al. 2017), bipolar disorder (Bersani et al. 2015; Pereira-Junior et al. 2015; Tortella et al. 2015), schizophrenia (Agarwal et al. 2013; Palm et al. 2016; Gögler et al. 2017), Alzheimer's disease (Nardone et al. 2012; Bystad et al. 2016; Narita and Yokoi 2017), modulation of associative learning (Branscheidt et al.
2017), Parkinson's disease (Benninger et al. 2010; Hendy et al. 2016; Schabrun et al. 2016), pain after stroke (Schjetnan et al. 2013; Chhatbar et al. 2016; Russo et al. 2017) and tinnitus (Garin et al. 2011; Teismann et al. 2014).

\section{tRNS}

tRNS has a frequency spectrum that is typically divided into low frequency $(0.1-100 \mathrm{~Hz})$ stimulation and high frequency $(100-640 \mathrm{~Hz})$ stimulation. This is an effective method of avoiding directional sensitivity associated with standard tDCS and sinusoidal tACS. To screen for the most efficient frequencies, within a physiological range, random noise frequency patterns are used (Terney et al. 2008), which have the potential to desynchronize (pathological) rhythms.

\section{$t A C S$}

tACS, which uses non-uniform flow for non-invasive transcranial stimulation, is still poorly understood. The simplest case involves stimulation using a single frequency harmonic signal in the range of $0.1-5000 \mathrm{~Hz}$. tACS appears to interact with ongoing rhythms in the cortex from $0.1 \mathrm{~Hz}$ (delta waves) up to over $60 \mathrm{~Hz}$ (gamma waves) on an EEG. Sinusoidal tACS allows manipulation of intrinsic cortical oscillations with externally applied electrical frequencies. Of course, combinations using any frequency are possible, the more frequencies involved, the closer the results approach the effects of tRNS. Evidence for a relationship between alpha EEG activity $(8-12 \mathrm{~Hz})$ and pain has also been investigated. tACS at alpha frequencies (alpha tACS) permits direct manipulation of brain alpha activity and therefore an examination of the potential causal relationship between alpha activity and pain (Arendsen et al. 2018). While somatosensory alpha tACS can reduce pain (Gundlach et al. 2016), inter-regional phase synchronization with dual-site tACS could be beneficial for modulation of specific cognitive processes in the human brain (Saturnino et al. 2017). tACS has also been found to be a promising method for boosting memory (Marshall et al. 2006. The intensity of tACS applied frontally is usually limited to $400 \mathrm{~mA}$ to avoid retinal phosphenes, which can occur at higher intensities (Antal and Paulus 2008, 2016). Other evidence for the influence of tACS can be seen in the motor cortex, where $20 \mathrm{~Hz}$ has been shown to slow down voluntary movements (Pogosyan et al. 2009). Also, it is possible to increase alpha power, via stimulation, by using a tACS frequency within the individual's EEG range (Zaehle et al. 2010). tACS seems set to open a new era of directly interfering with cortical rhythms and actively synchronizing cortical rhythms, although at present interference with phosphenes in the frequency range of about $10-40 \mathrm{~Hz}$ is a problem. This problem does not occur when tACS is used in the "ripple" frequency range (Moliadze et al. 2010). Ripples 
Table 1. Overview of brain stimulation methods

\begin{tabular}{|c|c|c|c|c|}
\hline Stimulation method & Treatment & References & Advantages & Disadvantages \\
\hline $\begin{array}{l}\text { DBS with implanted } \\
\text { electrodes }\end{array}$ & $\begin{array}{l}\text { Parkinson's disease, epilepsy, } \\
\text { dystonia, tremor, cluster } \\
\text { headache, chronic pain, pain } \\
\text { from stroke, amputation, } \\
\text { trigeminal neuralgia, multiple } \\
\text { sclerosis, obsessive-compulsive } \\
\text { disorder, Tourette's syndrome } \\
\text { depression }\end{array}$ & $\begin{array}{l}\text { Kringelbach et al. 2007; Pereira } \\
\text { et al. 2007, 2013; Holslag 2018; } \\
\text { Johnson et al. } 2008\end{array}$ & $\begin{array}{l}\text { Strong effect, } \\
\text { precise targeting, } \\
\text { personalized tuning } \\
\text { and targeting for } \\
\text { intended structure }\end{array}$ & $\begin{array}{l}\text { Invasive electrode } \\
\text { placement, } \\
\text { pacemaker } \\
\text { implanted under } \\
\text { the patient's skin }\end{array}$ \\
\hline $\begin{array}{l}\text { Wireless } \\
\text { magneto-thermal } \\
\text { DBS }\end{array}$ & & Chen et al. 2015 & $\begin{array}{l}\text { Noninvasive } \\
\text { application of the } \\
\text { magnetic field }\end{array}$ & $\begin{array}{l}\text { Invasive application } \\
\text { of magneto thermal } \\
\text { particles }\end{array}$ \\
\hline TMS & $\begin{array}{l}\text { Depression, schizophrenia, } \\
\text { Parkinson's disease, Alzheimer's } \\
\text { disease, various addictions }\end{array}$ & $\begin{array}{l}\text { Holtzheimer and McDonald } \\
\text { 2014; McNamara et al. 2001; } \\
\text { George and Belmaker 2007; } \\
\text { Prikryl et al. 2013; Fregni et al. } \\
\text { 2005; Ferreri et al. 2003; Li et al. } \\
\text { 2013; Politi et al. 2008; Shen et } \\
\text { al. 2016, } 2017\end{array}$ & Non-invasive & $\begin{array}{l}\text { Low spatial } \\
\text { targeting compared } \\
\text { to DBS, higher } \\
\text { cost compared to } \\
\text { other non-invasive } \\
\text { methods }\end{array}$ \\
\hline rTMS & pain & $\begin{array}{l}\text { Rokyta and Fricová 2012; } \\
\text { Fricová et al. 2013; Kohútová et } \\
\text { al. 2017; Robertson et al. 2010; } \\
\text { Thomas et al. 2007, Shupak et al. } \\
\text { 2006; Thomas et al. } 2001\end{array}$ & $\begin{array}{l}\text { Non-invasive, low } \\
\text { cost }\end{array}$ & $\begin{array}{l}\text { Less pronounced } \\
\text { effect compared to } \\
\text { rTMS }\end{array}$ \\
\hline tDCS & $\begin{array}{l}\text { chronic pain, trigeminal pain } \\
\text { including refractory orofacial } \\
\text { pain, fibromyalgia, major } \\
\text { depression, bipolar disorder, } \\
\text { schizophrenia, Alzheimer's } \\
\text { disease associative learning, } \\
\text { Parkinson's disease, pain after } \\
\text { stroke, tinnitus }\end{array}$ & $\begin{array}{l}\text { Souto et al. 2014; Hodaj et al. } \\
\text { 2016; Borckardt et al. 2011; } \\
\text { Antal et al. 2010; Hansen et al. } \\
\text { 2011; DosSantos et al. 2012; } \\
\text { Hagenacker et al. 2014; Kreuzer } \\
\text { et al. 2017; Fricova et al. 2016; } \\
\text { Castillo-Saavedra et al. 2018; } \\
\text { Valle et al. 2010; Tortella et al. } \\
\text { 2015; Liu et al. 2017; Vigod et } \\
\text { al. 2014; Brunoni et al. 2016; } \\
\text { Pereira-Junior et al. 2015; } \\
\text { Tortella et al. 2015; Bersani et al. } \\
\text { 2015; Palm et al. 2016; Gögler } \\
\text { et al. 2017; Agarwal et al. 2013; } \\
\text { Nardone et al. 2012; Narita and } \\
\text { Yokoi 2017; Bystad et al. 2016; } \\
\text { Branscheidt et al. 2017; Hendy } \\
\text { et al. 2016; Schabrun et al. 2016; } \\
\text { Benninger et al. 2010; Schjetnan } \\
\text { et al. 2013; Russo et al. 2017; } \\
\text { Teismann et al. 2014; Garin et } \\
\text { al. 2011 }\end{array}$ & $\begin{array}{l}\text { Non-invasive, low } \\
\text { cost }\end{array}$ & $\begin{array}{l}\text { Less pronounced } \\
\text { effect compared to } \\
\text { rTMS }\end{array}$ \\
\hline tRNS & $\begin{array}{l}\text { chronic pain, pain after stroke, } \\
\text { tinnitus }\end{array}$ & Terney et al. 2008 & $\begin{array}{l}\text { Non-invasive, low } \\
\text { cost }\end{array}$ & $\begin{array}{l}\text { Less pronounced } \\
\text { effect compared to } \\
\text { rTMS }\end{array}$ \\
\hline tACS & $\begin{array}{l}\text { Pain, modulation of cognitive } \\
\text { processes }\end{array}$ & $\begin{array}{l}\text { Gundlach et al. 2016; Saturnino } \\
\text { et al. 2017; Arendsen et al. 2018; } \\
\text { Marshall et al. 2006; Antal et al. } \\
2008\end{array}$ & $\begin{array}{l}\text { Non-invasive, low } \\
\text { cost promising }\end{array}$ & $\begin{array}{l}\text { Less pronounced } \\
\text { effect compared to } \\
\text { rTMS }\end{array}$ \\
\hline
\end{tabular}

DBS, deep brain stimulation; TMS, transcranial magnetic stimulation; rTMS, repetitive transcranial magnetic stimulation; tACS, transcranial alternating current stimulation; tDCS, transcranial direct current stimulation; tRNS, transcranial random noise stimulation. 
are short hippocampal oscillations with a frequency between $100-250 \mathrm{~Hz}$, which are associated with memory encoding.

\section{Interference tACS}

Interference tACS (if-tACS), as an analog of interferential therapy used in physiotherapy for significant physiological effects, may have the potential to modulate pain associated with deep brain structures. The goal of interferential therapy is to produce low frequency effects at sufficient intensity and at sufficient depth to avoid patient discomfort in the superficial tissues (i.e., the skin). Skin discomfort is related to the impedance of the skin being inversely proportional to the frequency of stimulation. The lower the stimulation frequency, the greater the impedance to the passage of the current and the greater the discomfort as current is 'pushed' into the tissues against this barrier. Skin, under normal conditions, (i.e., intact, room temperature, humidity $40-50 \%$ ) at $50 \mathrm{~Hz}$ has an impedance of approximately $3200 \mathrm{Ohms}$, while at $4000 \mathrm{~Hz}$ it drops to approximately $40 \mathrm{Ohms}$. The result of applying a higher frequency is that it will pass more easily through the skin and requires less electrical energy input to reach the deeper tissues, thereby causing less discomfort.

The clinical application of interferential therapy is based on peripheral nerve stimulation (frequency) data. Above $250 \mathrm{~Hz}$, electrical stimulation is without associated painful or unpleasant side effects. There are four main clinical applications of interferential therapy: pain relief (Johnson and Tabasam 2003; Hurley et al. 2004; Jorge et al. 2006; McManus et al. 2006; Walker et al. 2006; Atamaz et al. 2012; Gundog et al. 2012; Rocha 2012), muscle stimulation (Bircan et al. 2002; Bellew et al. 2012), increased local blood flow (Noble et al. 2000), and reduction of edema (Christie and Willoughby 1990; Jarit et al. 2003).

The physiological effects of tissue stimulation with medium frequency currents $(1-100 \mathrm{kHz})$ are not completely understood. When two of these medium frequency currents pass through the tissues simultaneously and in a direction such that their paths cross, they literally interfere with each other. This interaction gives rise to an interference current that has the characteristics of low frequency stimulation (in effect the interference mimics low frequency stimulation). The exact frequency of the resultant interference frequency can be controlled by the input frequencies. If, for example, one current is $5000 \mathrm{~Hz}$ and its companion current is 5020 $\mathrm{Hz}$, the resultant frequency would be at $20 \mathrm{~Hz}$, carried by median frequency $(5010 \mathrm{~Hz})$ amplitude modulated current (see Figure 3). The magnitude of the low frequency interference current is approximately equivalent to the sum of the input amplitudes. Low frequency currents are physiologically effective for nerve stimulation.

Although the theoretical basis for interferential therapy is incomplete, the positive effects have been convincingly documented. Proven physiological effects include local blood flow increase, local stimulation of neurons, and local muscle stimulation. Application of current interference to the brain (i.e., if-tACS) should be expected to produce effects in the brain similar to those seen in body tissues. Except for muscle stimulation, the potential should exist for increased local blood flow and local stimulation of neurons. Based on calculations of technical parameters, there is promising potential for if-tACS to reach, with proper electrode configurations, deep brain structures involved in pain generation and transmission. Therefore, if-tACS may be capable of modulating pain associated with specialized thalamic nuclei. Compared to standard invasive DBS, the if-tACS has substantially higher respect to the brain tissue, thus a significant benefit for patients. Once tACS testing is successfully completed, if-tACS will compete with other noninvasive neuro-modulatory methods (TMS, rTMS, tDCS, and tACS). A brief overview of brain stimulation methods discussed above can be found in Table 1.

\section{Conclusion}

Contemporary methods of transcranial stimulation utilized in pain treatment are widely accepted in everyday clinical practice and there is an abundance of experimental experience indicating their most appropriate uses, limits, application protocols, etc.

Invasive and non-invasive brain stimulation methods have been used, for more than two decades, as an alternative to pain pharmacotherapy or as the last choice in pharmaco-resistant pain. Even though the better-established techniques continue to evolve, there is still plenty of room for new approaches and new combinations of formerly verified methods. Because of the emergence of new techniques and technologies, future expansion can be expected in semi-invasive and non-invasive methods since they are safe and comfortable for the patient, are easy to apply, and are effective, i.e., affordable in routine use.

Acknowledgments. We thank Thomas Secrest for language and formal corrections. This publication was supported by a grant from the Czech Health Research Council No 15-31538A.

Conflict of interest. The authors declare no conflict of interest.

\section{References}

Abboud H, Hill E, Siddiqui J, Serra A, Walter B (2017): Neuromodulation in multiple sclerosis. Mult. Scler. 23, 1663-1676 https://doi.org/10.1177/1352458517736150

Adam J, Hosobuchi Y, Fields H (1974): Stimulation of the internal capsule for relief of chronic pain. J. Neurosurg. 4, 740-744 https://doi.org/10.3171/jns.1974.41.6.0740 
Ainsworth L, Budelier K, Clinesmith M, Fiedler A, Landstrom R, Leeper BJ, Moeller LA, Mutch S, O'Dell K, Ross J, Radhakrishnan R, Sluka KA (2006): Transcutaneous electrical nerve stimulation (TENS) reduces chronic hyperalgesia induced by muscle inflammation. Pain 120, 182-187 https://doi.org/10.1016/j.pain.2005.10.030

Agarwal SM, Shivakumar V, Bose A, Subramaniam A, Nawani H, Chhabra H, Kalmady SV, Narayanaswamy JC, Venkatasubramanian G (2013): Transcranial Direct Current Stimulation in Schizophrenia. Clin. Psychopharmacol. Neurosci. 11, 118-125 https://doi.org/10.9758/cpn.2013.11.3.118

Albe-Fessard D, Berkley KJ, Kruger L, Ralston HJ, Willis WD (1985): Diencephalic mechanisms of pain sensation. Brain Res. 356, 217-296 https://doi.org/10.1016/0165-0173(85)90013-X

Albornoz-Cabello M, Maya-Martín J, Domínguez-Maldonado G, Espejo-Antúnez L, Heredia-Rizo AM (2017): Effect of interferential current therapy on pain perception and disability level in subjects with chronic low back pain: a randomized controlled trial. Clin. Rehabil. 31, 242-249 https://doi.org/10.1177/0269215516639653

Amin B, Hosseinzadeh H (2015): Analgesic and anti-inflammatory effects of Crocus sativus L. (Saffron). In: Bioactive Nutraceuticals and Dietary Supplements in Neurological and Brain Disease. (Ed. Watson RR, Preedy VR), Elseviere

Andersen C, Rørth M, Ejlertsen B, Adamsen L (2014): Exercise despite pain--breast cancer patient experiences of muscle and joint pain during adjuvant chemotherapy and concurrent participation in an exercise intervention. Eur. J. Cancer Care (Engl.) 23, 653-67 https://doi.org/10.1111/ecc.12192

Angelakis E, Liouta E, Andreadis N, Leonardos A, Ktonas P, Stavrinou LC, Miranda PC, Mekonnen A, Sakas DE (2013): Transcranial alternating current stimulation reduces symptoms in intractable idiopathic cervical dystonia: a case study. Neurosci Lett. 533, 39-43 https://doi.org/10.1016/j.neulet.2012.11.007

Antal A, Paulus W (2008): Transcranial direct current stimulation and visual perception. Perception 37, 367-374 https://doi.org/10.1068/p5872

Antal A, Terney D, Kühnl S, Paulus W (2010): Anodal transcranial direct current stimulation of the motor cortex ameliorates chronic pain and reduces short intracortical inhibition. J. Pain Symptom. Manage 39, 890-903

https://doi.org/10.1016/j.jpainsymman.2009.09.023

Antal S, Fitzgerald J, Pereira E, Moir L, Van Hartevelt T, Kringelback M, Green A, Aziz T (2014): Targeting the affective component of chronic pain: A case series of deep brain stimulation of the anterior cingulate cortex. Neurosurgery 74, 628-635 https://doi.org/10.1227/NEU.0000000000000321

Antal A, Herrmann CS (2016): Transcranial alternating current and random noise stimulation: possible mechanisms. Neural Plast. 2016, 3616807 https://doi.org/10.1155/2016/3616807

Antal A, Alekseichuk I, Bikson M, Brockmöller J, Brunoni AR, Chen R, Cohen LG, Dowthwaite G, Ellrich J, Flöel A, et al. (2017): Low intensity transcranial electric stimulation: Safety, ethical, legal regulatory and application guidelines. Clinical Neurophysiology 128, 1774-1809 https://doi.org/10.1016/j.clinph.2017.06.001

Arendsen LJ, Hugh-Jones, Lloyd DM (2018): Transcranial alternating current stimulation at alpha frequency reduces pain when the intensity of pain is uncertain. J. Pain (in press)

Atamaz FC, Durmaz B, Baydar M, Demircioglu OY, Iyiyapici A, Kuran B, Oncel S, Sendur OFl (2012): Comparison of the efficacy of transcutaneous electrical nerve stimulation, interferential currents, and shortwave diathermy in knee osteoarthritis: a double-blind, randomized, controlled, multicenter study. Arch. Phys. Med. Rehabil. 93, 748-756 https://doi.org/10.1016/j.apmr.2011.11.037

Babatunde OO, Legha A, Littlewood C, Chesterton LS, Thomas MJ, Menz HB, van der Windt D, Roddy E (2018): Comparative effectiveness of treatment options for plantar heel pain: a systematic review with network meta-analysis. Br. J. Sports Med. (in press)

Bae YH, Lee SM (2014): Analgesic effects of transcutaneous electrical nerve stimulation and interferential current on experimental ischemic pain models: frequencies of $50 \mathrm{~Hz}$ and $100 \mathrm{~Hz}$. J. Phys. Ther. Sci. 26, 1945-1948 https://doi.org/10.1589/jpts.26.1945

Basbaum AI, Bautista DM, Scherrer G, Julius D (2009): Cellular and molecular mechanisms of pain. Cell 139, 267-284 https://doi.org/10.1016/j.cell.2009.09.028

Basser PJ, Roth BJ (2000): New currents in electrical stimulation of excit- able tissues. Annu. Rev. Biomed. Eng. 2, 377-397 https://doi.org/10.1146/annurev.bioeng.2.1.377

Bellew JW, Beiswanger Z, Freeman E, Gaerte C, Trafton J (2012): Interferential and burst-modulated biphasic pulsed currents yield greater muscular force than Russian current. Physiother. Theory Pract. 28, 384-390 https://doi.org/10.3109/09593985.2011.637286

Benabid AL (2014): Neuroscience: spotlight on deep-brain stimulation. Nature 2015, 299-300

Benninger DH, Lomarev M, Lopez G, Wassermann EM, Li X, Considine E, Hallett M (2010): Transcranial direct current stimulation for the treatment of Parkinson's disease. J. Neurol. Neurosurg. Psychiatry 81, 1105-1111 https://doi.org/10.1136/jnnp.2009.202556

Bersani FS, Minichino A, Fattapposta F, Bernabei L, Spagnoli F, Mannarelli D, Francesconi M, Pauletti C, Corrado A, Vergnani L, et al. (2015): Prefrontocerebellar transcranial direct current stimulation increases amplitude and decreases latency of P3b component in patients with euthymic bipolar disorder. Neuropsychiatr. Dis. Treat. 11, 2913-2917 https://doi.org/10.2147/NDT.S91625

Bircan C, Senocak O, Peker O, Kaya A, Tamci SA, Gulbahar S, Akalin E (2002): Efficacy of two forms of electrical stimulation in increasing quadriceps strength: a randomized controlled trial. Clin. Rehabil. 16, 194-199 https://doi.org/10.1191/0269215502cr467oa

Bigley GK (1990): Sensation. In: Clinical Methods: The History, Physical, and Laboratory Examinations. (Eds: Walker HK, Hall WD, Hurst JW), 3rd edition, Chapter 67, Boston: Butterworths Bittar RG, Kar-Purkayastha I, Owen SL, Bear RE, Green A, Wang S, Aziz TZ (2005): Deep brain stimulation for pain relief: A metaanalysis. J. Clin. Neurosci. 12, 515-519 https://doi.org/10.1016/j.jocn.2004.10.005 
Boccard SG, Pereira EA, Moir L, Van Hartevelt TJ, Kringelbach ML, FitzGerald JJ, Baker IW, Green AL, Aziz TZ (2014): Deep brain stimulation of the anterior cingulate cortex: targeting the affective component of chronic pain. Neuroreport 25, 83-88 https://doi.org/10.1097/WNR.0000000000000039

Borckardt JJ, Romagnuolo J, Reeves ST, Madan A, Frohman H, Beam W, George MS (2011): Feasibility, safety, and effectiveness of transcranial direct current stimulation for decreasing post-ERCP pain: a randomized, sham-controlled, pilot study. Gastrointest. Endosc. 73, 1158-1164 https://doi.org/10.1016/j.gie.2011.01.050

Branscheidt M, Hoppe J, Freundlieb N, Zwitserlood P, Liuzzi G (2017): tDCS over the motor cortex shows differential effects on action and object words in Associative Word Learning in Healthy Aging. Front. Aging Neurosci. 9, 13 https://doi.org/10.3389/fnagi.2017.00137

Brunoni AR, Moffa AH, Fregni F, Palm U, Padberg F, Blumberger DM, Daskalakis ZJ, Bennabi D, Haffen E, Alonzo A, Loo CL (2016): Transcranial direct current stimulation for acute major depressive episodes: meta-analysis of individual patient data. Br. J. Psychiatry 208, 522-531 https://doi.org/10.1192/bjp.bp.115.164715

Bystad M, Grønli O, Rasmussen id, Gundersen N, Nordvang L, Wang-Iversen H, Aslaksen PM (2016): Transcranial direct current stimulation as a memory enhancer in patients with Alzheimer's disease: a randomized, placebo-controlled trial. Alzheimers Res. Ther. 8, 13 https://doi.org/10.1186/s13195-016-0180-3

Camalier CR, McHugo M, Zald DH, Neimat JS (2018): The effect of deep brain stimulation therapy on fear-related capture of attention in Parkinson's disease and essential tremor: A comparison to healthy individuals. J. Neurol. Disord. 6, 377 https://doi.org/10.4172/2329-6895.1000377

Castillo-Saavedra L, Gebodh N, Bikson M, Diaz-Cruz C, Brandao R, Coutinho L, Truong D, Datta A, Shani-Hershkovich R, Weiss M, et al. (2018): Clinically effective treatment of fibromyalgia pain with high-definition transcranial direct current stimulation: phase II open-label dose optimization. J. Pain $17,14-26$ https://doi.org/10.1016/j.jpain.2015.09.009

Chabardès S, Carron R, Seigneuret E, Torres N, Goetz L, Krainik A, Piallat B, Pham P, David O, Giraud P, Benabid AL (2016): Endoventricular deep brain stimulation of the third ventricle: proof of concept and application to cluster headache. Neurosurgery 79, 806-815 https://doi.org/10.1227/NEU.0000000000001260

Chan AY, Rolston JD, Rao VR, Chang EF (2018): Effect of neurostimulation on cognition and mood in refractory epilepsy. Epilepsia Open 3, 18-29 https://doi.org/10.1002/epi4.12100

Chen R, Romero G, Christiansen MG, Anikeeva AMP (2015): Wireless magnetothermal deep brain stimulation. Science 27, 1477-1480 https://doi.org/10.1126/science.1261821

Chhatbar PY, Ramakrishnan V, Kautz S, George MS, Adams RJ, Feng W (2016): Transcranial direct current stimulation poststroke upper extremity motor recovery studies exhibit a doseresponse relationship. Brain Stimul. 9, 16-26 https://doi.org/10.1016/j.brs.2015.09.002

Christie AD, Willoughby GL (1990): The effect of interferential therapy on swelling following open reduction and internal fixation of ankle fractures. Physiotherapy Theory and Practice 6, 3-7 https://doi.org/10.3109/09593989009087750

Ciofani G, Danti S, D'Alessandro D, Ricotti L, Moscato S, Bertoni $G$ (2010): Enhancement of neurite outgrowth in neuronal-like cells following boron nitride nanotube-mediated stimulation. ACS Nano 4, 6267-6277 https://doi.org/10.1021/nn101985a

Crofford LJ (2015a): Chronic pain: where the body meets the brain. Trans. Am. Clin. Climatol. Assoc. 126, 167-183

Crofford LJ (2015b): Psychological aspects of chronic musculoskeletal pain. Best Pract. Res. Clin. Rheumatol. 29, 147-155 https://doi.org/10.1016/j.berh.2015.04.027

Cummiford CM, Nascimento TD, Foerster BR, Clauw DJ, Zubieta JK, Harris RE, DaSilva AF (2016): Changes in resting state functional connectivity after repetitive transcranial direct current stimulation applied to motor cortex in fibromyalgia patients. Arthritis Res. Ther. 18, 40 https://doi.org/10.1186/s13075-016-0934-0

Curatolo M, La Bianca G, Cosentino G, Baschi R, Salemi G, Talotta R, Romano M, Triolo G, De Tommaso M, Fierro B, Brighina F (2017): Motor cortex tRNS improves pain, affective and cognitive impairment in patients with fibromyalgia: preliminary results of a randomised sham-controlled trial. Clin. Exp. Rheumatol. 35 (Suppl. 105), 100-105

D‘Agata F, Cicerale A, Mingolla A, Caroppo P, Orsi L, Mortara P, Troni W, Pinessi L (2015): Double-cone coil tms stimulation of the medial cortex inhibits central pain habituation. PLoS One 10, e0128765 https://doi.org/10.1371/journal.pone.0128765

Dailey DL, Rakel BA, Vance CG, Liebano RE, Amrit AS, Bush HM, Lee KS, Lee JE, Sluka KA (2013): Transcutaneous electrical nerve stimulation reduces pain, fatigue and hyperalgesia while restoring central inhibition in primary fibromyalgia. Pain 154, $2554-2562$ https://doi.org/10.1016/j.pain.2013.07.043

Davis KD, Lozano A, Tasker R, Dostrovsky J (1998): Brain targets for pain control. Stereotact. Funct. Neurosurg. 71, 173-179 https://doi.org/10.1159/000029661

Deer TR, Mekhail N, Petersen E, Krames E, Staats P, Pope J, Saweris Y, Lad SP, Diwan S, Falowski S, et al. (2014): The appropriate use of neurostimulation: stimulation of the intracranial and extracranial space and head for chronic pain. Neuromodulation Appropriateness Consensus Committee. Neuromodulation 6, $551-570$ https://doi.org/10.1111/ner.12215

DosSantos MF, Love TM, Martikainen IK, Nascimento TD, Fregni F, Cummiford C, Deboer MD, Zubieta JK, Dasilva AF (2012): Immediate effects of tDCS on the $\mu$-opioid system of a chronic pain patient. Front. Psychiatry 2, 93

Duecker M, de Graaf TA, Sack AT (2014): Thinking caps for everyone? The role of neuro-enhancement by non-invasive brain stimulation in neuroscience and beyond. Front. Syst. Neurosci. 8, 71 https://doi.org/10.3389/fnsys.2014.00071 
Duncan GH, Bushnell MC, Marchand S (1991): Deep brain stimulation: A review of basic research and clinical studies. Pain 45, 49-59 https://doi.org/10.1016/0304-3959(91)90164-S

Eke-Okoro UJ, Raffa RB, Pergolizzi JV Jr, Breve F, Taylor R Jr (2018): Curcumin in turmeric: Basic and clinical evidence for a potential role in analgesia. J. Clin. Pharm. Ther. 43, 460-466 https://doi.org/10.1111/jcpt.12703

Elnaggar RK, Elshafey MA (2016): Effects of combined resistive underwater exercises and interferential current therapy in patients with juvenile idiopathic arthritis: a randomized controlled trial. Am. J. Phys. Med. Rehabil. 95, 96-102 https://doi.org/10.1097/PHM.0000000000000347

Eom K, Kim J, Choi JM, Kang T, Chang JW, Byun KM (2014): Enhanced infrared neural stimulation using localized surface plasmon resonance of gold nanorods. Small 10, 3853-3857 https://doi.org/10.1002/smll.201400599

Ferreri F, Pasqualetti P, Maatta S, Ponzo D, Guerra A, Bressi F, Chiovenda P, Del Duca M, Giambattistelli F, Ursini F, et al. (2003): Motor cortex excitability in Alzheimer's disease: a transcranial magnetic stimulation study. Ann. Neurol. 53, 102-108 https://doi.org/10.1002/ana.10416

Finch PM, Drummond PD (2015): Topical treatment in pain medicine: from ancient remedies to modern usage. Pain Management 5, 359

https://doi.org/10.2217/pmt.15.23

Flor H (2014): Psychological pain interventions and neurophysiology: implications for a mechanism-based approach. Am. Psychol. 69, 188-196 https://doi.org/10.1037/a0035254

Franco KM, Franco YD, Oliveira NB, Miyamoto GC, Santos MO, Liebano RE, Cabral CN (2017): Is interferential current before pilates exercises more effective than placebo in patients with chronic nonspecific low back pain? A randomized controlled trial. Arch. Phys. Med. Rehabil. 98, 320-328 https://doi.org/10.1016/j.apmr.2016.08.485

Franzini A, Messina G, Gambini O (2010): Deep-brain stimulation of the nucleus accumbens in obsessive compulsive disorder: Clinical, surgical and electrophysiological considerations in two consecutive patients. Neurol. Sci. 31, 353-359 https://doi.org/10.1007/s10072-009-0214-8

Franzini A, Ranieri R, Gambini O, Messina G (2018): Manipulating an internal pulse generator until twiddler's syndrome in a patient treated with deep brain stimulation for obsessivecompulsive disorder. Acta Neurochir. (Wien) 160, 389-392 https://doi.org/10.1007/s00701-017-3412-9

Fregni F, Simon DK, Wu A, Pascual-Leone A (2005): Non-invasive brain stimulation for Parkinson's disease: a systematic review and meta-analysis of the literature. J. Neurol. Neurosurg. Psychiatr. 76, 1614-1623 https://doi.org/10.1136/jnnp.2005.069849

Fricova J, Englerova K, Rokyta R (2016): Noninvasive transcranial direct current stimulation (tDCS) for the treatment of orofacial pain. Neuro. Endocrinol. Lett. 37, 368-372

Fricová J, Klírová M, Masopust V, Novák T, Vérebová K, Rokyta R (2013): Repetitive transcranial magnetic stimulation in the treatment of chronic orofacial pain. Physiol. Res. 62, 125-134
Gijon-Nogueron G, Ramos-Petersen L, Ortega-Avila AB, MoralesAsencio JM, Garcia-Mayor S (2018): Effectiveness of foot orthoses in patients with rheumatoid arthritis related to disability and pain: a systematic review and meta-analysis. Qual. Life Res. (in print) https://doi.org/10.1007/s11136-018-1913-5

Garin P, Gilain C, VanDamme JP, deFays K, Jamart J, Ossemann M, Vandermeeren Y (2011): Short- and long-lasting tinnitus relief induced by transcranial direct current stimulation. J. Neurol. 258, 1940-1952 https://doi.org/10.1007/s00415-011-6037-6

George MS, Belmaker RH (2007): Transcranial Magnetic Stimulation in Clinical Psychiatry. Arlington, TX, American Psychiatric Publishing

Gerhart KD, Yezierski RP, Fang ZR, Willis WD (1983): Inhibition of primate spinothalamic tract neurons by stimulation in ventral posterior lateral (VPLc): thalamic nucleus: Possible mechanisms. J. Neurophysiol. 49, 406-423 https://doi.org/10.1152/jn.1983.49.2.406

Gögler N, Papazova I, Oviedo-Salcedo T, Filipova N, Strube W, Funk J, Müller HJ, Finke K, Hasan A (2017): Parameter-based evaluation of attentional impairments in schizophrenia and their modulation by prefrontal transcranial direct current stimulation. Front. Psychiatry 17, 259 https://doi.org/10.3389/fpsyt.2017.00259

Gopalakrishnan R, Burgess RC, Malone DA, Lempka SF, Gale JT, Floden DP, Baker KB, Machado A (2018): Deep brain stimulation of the ventral striatal area for post-stroke pain syndrome: a magnetoencephalography study. J. Neurophysiol. (in press) https://doi.org/10.1152/jn.00830.2017

Gundlach C, Müller MM, Nierhaus T, Villringer A, Sehm B (2016): Phasic modulation of human somatosensory perception by transcranially applied oscillating currents. Brain Stimul. 9, 712-719 https://doi.org/10.1016/j.brs.2016.04.014

Gundog M, Atamaz F, Kanyilmaz S, Kirazli Y, Celepoglu G (2012): Interferential current therapy in patients with knee osteoarthritis: comparison of the effectiveness of different amplitude-modulated frequencies. Am. J. Phys. Med. Rehabil. 91, 107-113 https://doi.org/10.1097/PHM.0b013e3182328687

Hagenacker T, Bude V, Naegel S, Holle D, Katsarava Z, Diener HC, Obermann M (2014): Patient-conducted anodal transcranial direct current stimulation of the motor cortex alleviates pain in trigeminal neuralgia. J. Headache Pain 25, 78 https://doi.org/10.1186/1129-2377-15-78

Hallett M (2007): Transcranial magnetic stimulation: a primer. Neuron 55, 187- 199 https://doi.org/10.1016/j.neuron.2007.06.026

Hansen N, Obermann M, Poitz F, Holle D, Diener HC, Antal A, Paulus W, Katsarava Z (2011): Modulation of human trigeminal and extracranial nociceptive processing by transcranial direct current stimulation of the motor cortex. Cephalalgia 31, 661-670 https://doi.org/10.1177/0333102410390394

Hariz MI, Bergenheim AT (1995): Thalamic stereotaxis for chronic pain: Ablative lesion or stimulation? Stereotact. Funct. Neurosurg. 64, 47-55 https://doi.org/10.1159/000098733 
Harrison AP, Hansen SH, Bartels EM (2012): Transdermal opioid patches for pain treatment in ancient Greece. Pain Practice 12,620 https://doi.org/10.1111/j.1533-2500.2012.00546.x

Hartl E, Bötzel K, Mehrkens JH, Noachtar S (2018): Seizure reductions outlast DBS explantation. Brain Stimul. 11, 636-638 https://doi.org/10.1016/j.brs.2018.01.033

Hasegawa Y, Sugahara K, Sano S, Sakuramoto A, Kishimoto H, Oku Y (2016): Enhanced salivary secretion by interferential current stimulation in patients with dry mouth: a pilot study. Oral Surg. Oral Med. Oral Pathol. Oral Radiol. 121, 481-489 https://doi.org/10.1016/j.oooo.2016.01.017

Hauptman JS, DeSalles AA, Espinoza R, Sedrak M, Ishida W (2008): Potential surgical targets for deep brain stimulation in treatment-resistant depression. Neurosurg. Focus 25, E9 https://doi.org/10.3171/FOC/2008/25/7/E3

Hazime FA, de Freitas DG, Monteiro RL, Maretto RL, Carvalho NA, Hasue RH, João SM (2015): Analgesic efficacy of cerebral and peripheral electrical stimulation in chronic nonspecific low back pain: a randomized, double-blind, factorial clinical trial. BMC Musculoskelet Disord. 31, 16:7 https://doi.org/10.1186/s12891-015-0461-1

Hécaen H, Talairach J, David M, Dell MB (1949): Coagulations limitées du thalamus dans les algies du syndrome thalamique. Rev. Neurol. 81, 917-931

Hendy AM, Tillman A, Rantalainen T, Muthalib M, Johnson L, Kidgell DJ, Wundersitz D, Enticott PG, Teo WP (2016): Concurrent transcranial direct current stimulation and progressive resistance training in Parkinson's disease: study protocol for a randomised controlled trial. Trials 17, 326 https://doi.org/10.1186/s13063-016-1461-7

Hirato M, Kawashima Y, Shibazaki T, Shibasaki T, Ohye C (1991): Pathophysiology of central (thalamic): pain: A possible role of the intralaminar nuclei in superficial pain. Acta Neurochir. 52, 133-136 https://doi.org/10.1007/978-3-7091-9160-6_36

Hirayama A, Saitoh Y, Kishima H, Shimokawa T, Oshino S, Hirata M, Kato A, Yoshimine T (2006): Reduction of intractable deafferentation pain by navigation-guided repetitive transcranial magnetic stimulation of the primary motor cortex. Pain 122, $22-27$ https://doi.org/10.1016/j.pain.2005.12.001

Hodaj H, Payen JF, Lefaucheur JP (2016): A case of long-term treatment of chronic pain syndrome by anodal tdcs of the motor cortex, previously resistant to high-frequency rtms and implanted spinal cord stimulation. Brain Stimul. 9, 618-620 https://doi.org/10.1016/j.brs.2016.02.008

Hollingworth M, Sims-Williams HP, Pickering AE, Barua N, Patel NK (2017): Single electrode deep brain stimulation with dual targeting at dual frequency for the treatment of chronic pain: a case series and review of the literature. Brain Sci. 7, 9 https://doi.org/10.3390/brainsci7010009

Holslag J (2018): Deep brain stimulation for essential tremor: a comparison of targets. World Neurosurgery 110, e580-584 https://doi.org/10.1016/j.wneu.2017.11.064

Holtzheimer PE, McDonald WM (2014): A Clinical Guide to Transcranial Magnetic Stimulation. Oxford University Press, Oxford https://doi.org/10.1093/med/9780199926480.001.0001
Huang H, Delikanli S, Zeng H, Ferkey DM, Pralle A (2010): Remote control of ion channels and neurons through magnetic-field heating of nanoparticles. Nat. Nanotechnol. 5, 602-606 https://doi.org/10.1038/nnano.2010.125

Hurley DA, McDonough SM, Dempster M, Moore AP, Baxter GD (2004): A randomized clinical trial of manipulative therapy and interferential therapy for acute low back pain. Spine 29, 2207-2216 https://doi.org/10.1097/01.brs.0000142234.15437.da

Ibrahim MM, Porreca F, Lai J, Albrecht PJ, Rice FL, Khodorova A, Davar G, Makriyannis A, Vanderah TW, Mata HP, Malan TP (2005): CB2 cannabinoid receptor activation produces antinociception by stimulating peripheral release of endogenous opioids. PNAS 102, 3093-3098 https://doi.org/10.1073/pnas.0409888102

Jarit GJ, Mohr KJ, Waller R, Glousman RE (2003): The effects of home interferential therapy on post-operative pain, edema, and range of motion of the knee. Clin. J. Sport Med. 13, 16-20 https://doi.org/10.1097/00042752-200301000-00004

Johnson MI, Tabasam G (2003): A single-blind investigation into the hypoalgesic effects of different swing patterns of interferential currents on cold-induced pain in healthy volunteers. Arch. Phys. Med. Rehabil. 84, 350-357 https://doi.org/10.1053/apmr.2003.50005

Johnson MI, Oxberry SG, Robb K (2008): Stimulation-induced analgesia. In: Clinical Pain Management: Cancer Pain. (Eds. Sykes N, Bennett MI, Yuan CS), 2nd ed., pp. 235-250, London: Hodder Arnold.

Johnson MI, Claydon LS, Herbison GP, Jones G, Paley CA (2017): Transcutaneous electrical nerve stimulation (TENS) for fibromyalgia in adults. Cochrane Database Syst Rev. 10, CD012172 https://doi.org/10.1002/14651858.CD012172.pub2

Jorge S, Parada CA, Ferreira SH, Tambeli CH (2006): Interferential therapy produces antinociception during application in various models of inflammatory pain. Phys. Ther. 86, 800-808

Kalra A, Urban, MO, Sluka KA (2001): Blockade of opioid receptors in rostral ventral medulla prevents antihyperalgesia produced by transcutaneous electrical nerve stimulation (TENS). J. Pharmacol. Exp. Ther. 298, 257-263

Kohútová B, Fricová J, Klírová M, Novák T, Rokyta R (2017): Theta burst stimulation in the treatment of chronic orofacial pain: a randomized controlled trial. Physiol. Res. 66,1041-1047

Kreuzer PM, Vielsmeier V, Poeppl TB, Langguth B (2017): A case report on red ear syndrome with tinnitus successfully treated with transcranial random noise stimulation. Pain Physician 20, E199-205

Kringelbach ML, Jenkinson N, Green AL, Owen SLF, Hansen PC, Cornelissen PL, Holliday IE, Stein J, Aziz TZ (2007a): Deep brain stimulation for chronic pain investigated with magnetoencephalography. Neuroreport 18, 223-228 https://doi.org/10.1097/WNR.0b013e328010dc3d

Kringelbach ML, Jenkinson N, Owen SL, Aziz TZ (2007b): Translational principles of deep brain stimulation. Nature Reviews Neuroscience 8, 623-635 https://doi.org/10.1038/nrn2196

Kuffler DP (2018): Coping with phantom limb pain. Mol. Neurobiol. 55, 70-84 https://doi.org/10.1007/s12035-017-0718-9 
Kunz P, Antal A, Hewitt M, Neef A, Opitz A, Paulus W (2017): 5 $\mathrm{kHz}$ transcranial alternating current stimulation: lack of cortical excitability changes when grouped in a theta burst pattern. Front. Hum. Neurosci. 10, 683 https://doi.org/10.3389/fnhum.2016.00683

Ladi-Seyedian SS, Sharifi-Rad L, Manouchehri N, Ashjaei B (2017): A comparative study of transcutaneous interferential electrical stimulation plus behavioral therapy and behavioral therapy alone on constipation in postoperative Hirschsprung disease children. J. Pediatr. Surg. 52, 177-183 https://doi.org/10.1016/j.jpedsurg.2016.07.007

Láinez MJ, Guillamón E (2017): Cluster headache and other TACs: Pathophysiology and neurostimulation options. Headache 57, 327-335 https://doi.org/10.1111/head.12874

Lefaucheur JP (2008): Use of repetitive transcranial magnetic stimulation in pain relief. Expert. Rev. Neurother. 8, 799-808 https://doi.org/10.1586/14737175.8.5.799

Lempka SF, Malone DA Jr, Hu B, Baker KB, Wyant A, Ozinga JG 4th, Plow EB, Pandya M, Kubu CS, Ford PJ, Machado AG (2017): Randomized clinical trial of deep brain stimulation for poststroke pain. Ann. Neurol. 81, 653-663 https://doi.org/10.1002/ana.24927

Levine JD, Taiwo YO (1989): Involvement of the mu-opiate receptor in peripheral antihyperalgesia. Neuroscience 32, 571-575 https://doi.org/10.1016/0306-4522(89)90279-0

Li X, Hartwell KJ, Owens M, Lematty T, Borckardt JJ, Hanlon CA, Brady KT, George MS (2013): Repetitive transcranial magnetic stimulation of the dorsolateral prefrontal cortex reduces nicotine cue craving. Biol. Psychiatry 73, 714-720 https://doi.org/10.1016/j.biopsych.2013.01.003

Liu S, Sheng J, Li B, Zhang X (2017): Recent advances in noninvasive brain stimulation for major depressive disorder. Front. Hum. Neurosci. 11, 526 https://doi.org/10.3389/fnhum.2017.00526

Lobato-Polo J, Ospina-Delgado D, Orrego-González E, GómezCastro JF, Orozco JL, Enriquez-Marulanda A (2018): Deep brain stimulation surgery for status dystonicus: a singlecenter experience and literature review. World Neurosurg. 114, e992-1001 https://doi.org/10.1016/j.wneu.2018.03.129

Lorenz J, Minoshima S, Casey KL (2003): Keeping pain out of mind: The role of the dorsolateral prefrontal cortex in pain modulation. Brain 126, 1079-1091 https://doi.org/10.1093/brain/awg102

$\mathrm{Lu}$ M, Ueno S (2017): Comparison of the induced fields using different coil configurations during deep transcranial magnetic stimulation. PLoS ONE 6, 1-12 https://doi.org/10.1371/journal.pone.0178422

Lugo K, Miao X, Rieke F, Lin LY (2012): Remote switching of cellular activity and cell signaling using light in conjunction with quantum dots. Biomed. Opt. Express 3, 447-454 https://doi.org/10.1364/BOE.3.000447

Ma W, Eisenach JC (2002): Morphological and pharmacological evidence for the role of peripheral prostaglandins in the pathogenesis of neuropathic pain. Eur. J. Neurosci. 15, 1037-1047 https://doi.org/10.1046/j.1460-9568.2002.01940.x
Magown P, Andrade RA, Soroceanu A, Kiss ZHT (2018): Deep brain stimulation parameters for dystonia: A systematic review. Parkinsonism Relat. Disord. (in press) https://doi.org/10.1016/j.parkreldis.2018.04.017

Mallory GW, Abulseoud O, Hwang S, Gorman D, Stead S, Klassen B, Sandroni P, Watson J, Lee K (2012): The nucleus accumbens as a potential target for central poststroke pain. Mayo Clin. Proc. 87, 1025-1031 https://doi.org/10.1016/j.mayocp.2012.02.029

Marceglia S, Rosa M, Servello D, Porta M, Barbieri S, Moro E, Priori A (2017): Adaptive deep brain stimulation (adbs): for tourette syndrome. Brain Sci. 8, E4 https://doi.org/10.3390/brainsci8010004

Marshall L, Helgadottir H, Molle M, Born J (2006): Boosting slow oscillations during sleep potentiates memory. Nature 444, 610-613 https://doi.org/10.1038/nature05278

Martinez-Ramirez D, Jimenez-Shahed J, Leckman JF, Porta M, Servello D, Meng FG, Kuhn J, Huys D, Baldermann JC, Foltynie T, et al. (2018): Efficacy and safety of deep brain stimulation in tourette syndrome: the international tourette syndrome deep brain stimulation public database and registry. JAMA Neurol. $75,353-359$ https://doi.org/10.1001/jamaneurol.2017.4317

Mayer D, Liebeskind J (1974): Pain reduction by focal electrical stimulation of the brain: An anatomical and behavioral analysis. Brain Res. 68, 73-93 https://doi.org/10.1016/0006-8993(74)90534-4

Mazars GJ, Merienne L, Ciolocca C (1973): Stimulations thalmiques intermittentes antalgiques. Note Prelim. Rev. Neurol. 128, 273-279

McManus FJ, Ward AR, Robertson VJ (2006): The analgesic effects of interferential therapy on two experimental pain models: cold and mechanically induced pain. Physiotherapy 92, 95-102 https://doi.org/10.1016/j.physio.2005.09.007

McNamara B, Ray JL, Arthurs OJ, Boniface S (2001): Transcranial magnetic stimulation for depression and other psychiatric disorders. Psychol. Med. 31, 1141-1146 https://doi.org/10.1017/S0033291701004378

Mehreen A, Waheed M, Liaqat I, Arshad N (2016): Phytochemical, antimicrobial, and toxicological evaluation of traditional herbs used to treat sore throat. BioMed. Research International 1,8503426 https://doi.org/10.1155/2016/8503426

Melzack R, Wall PD (1965): Pain mechanisms: a new theory (review). Science 150, 971-979

https://doi.org/10.1126/science.150.3699.971

Moliadze V, Antal A, Paulus W (2010): Boosting brain excitability by transcranial high frequency stimulation in the ripple range. J. Physiol. 588, 4891-4904 https://doi.org/10.1113/jphysiol.2010.196998

Moldovan AS, Hartmann CJ, Trenado C, Meumertzheim N, Slotty PJ, Vesper J, Schnitzler A, Groiss SJ (2017): Less is more - pulse width dependent therapeutic window in deep brain stimulation for essential tremor. Brain Stimul. (in press) https://doi.org/10.1016/j.brs.2017.01.235

Monticone M, Cedraschi C, Ambrosini E, Rocca B, Fiorentini R, Restelli M, Gianola S, Ferrante S, Zanoli G, Moja L (2015): 
Cognitive-behavioural treatment for subacute and chronic neck pain. Cochrane Database Syst. Rev. 26, CD010664 https://doi.org/10.1002/14651858.CD010664.pub2

Moore RA, Derry S, Wiffen PJ, Straube S, Aldington DJ (2015): Overview review: Comparative efficacy of oral ibuprofen and paracetamol (acetaminophen) across acute and chronic pain conditions. Eur. J. Pain 9, 1213-1223

https://doi.org/10.1002/ejp.649

Naesström M, Blomstedt P, Hariz M, Bodlund O (2017): Deep brain stimulation for obsessive-compulsive disorder: Knowledge and concerns among psychiatrists, psychotherapists and patients. Surg. Neurol. Int. 6, 298 https://doi.org/10.4103/sni.sni_19_17

Nardone R, Bergmann J, Christova M, Caleri F, Tezzon F, Ladurner G, Trinka E, Golaszewski S (2012): Effect of transcranial brain stimulation for the treatment of alzheimer disease: a review. Int. J. Alzheimer's Dis. 2012, 687909 https://doi.org/10.1155/2012/687909

Narita Z, Yokoi Y (2017): Transcranial direct current stimulation for depression in Alzheimer's disease: study protocol for a randomized controlled trial. Trials 18, 285 https://doi.org/10.1186/s13063-017-2019-z

Nitsche MA, Paulus W (2000): Excitability changes induced in the human motor cortex by weak transcranial direct current stimulation. J. Physiol. 527, 633-639 https://doi.org/10.1111/j.1469-7793.2000.t01-1-00633.x

Nitsche MA, Paulus W (2001): Sustained excitability elevations induced by transcranial DC motor cortex stimulation in humans. Neurology 57, 1899-1901 https://doi.org/10.1212/WNL.57.10.1899

Nitsche MA, Schauenburg A, Lang N, Liebetanz D, Exner C, Paulus W, Tergau F (2003): Facilitation of implicit motor learning by weak transcranial direct current stimulation of the primary motor cortex in the human. J. Cognit. Neurosci. 15, 619-626 https://doi.org/10.1162/089892903321662994

Nitsche MA, Cohen LG, Wassermann EM, Priori A, Lang N, Antal A, Paulus W, Hummel F, Boggio PS, Fregni F, Pascual-Leone A (2008): Transcranial direct current stimulation: State of the art. Brain Stimulation 1, 206-223 https://doi.org/10.1016/j.brs.2008.06.004

Nizard J, Raoul S, Nguyen JP, Lefaucheur JP (2012): Invasive stimulation therapies for the treatment of refractory pain. Discov. Med. 14, 237-246

Noble JG, Henderson G, Cramp AF, Walsh DM, Lowe AS (2000): The effect of interferential therapy upon cutaneous blood flow in humans. Clin. Physiol. 20, 2-7 https://doi.org/10.1046/j.1365-2281.2000.00207.x

Obara I, Goulding SP, Hu JH, Klugmann M, Worley PF, Szumlinski KK (2013): Nerve injury-induced changes in Homer/glutamate receptor signaling contribute to the development and maintenance of neuropathic pain. Pain 154, 1932-1945 https://doi.org/10.1016/j.pain.2013.03.035

O‘Connell NE, Marston L, Spencer S, DeSouza LH, Wand BM (2018): Non-invasive brain stimulation techniques for chronic pain. Cochrane Database Syst Rev. 4, CD008208

Olds J, Milner P (1954): Positive reinforcement produced by electrical stimulation of septal area and other regions of rat brain. J. Comp. Physiol. Psychol. 47, 419-427 https://doi.org/10.1037/h0058775

Oliveria SF, Rodriguez RL, Bowers D, Kantor D, Hilliard JD, Monari EH, Scott BM, Okun MS, Foote KD (2017): Safety and efficacy of dual-lead thalamic deep brain stimulation for patients with treatment-refractory multiple sclerosis tremor: a single-centre, randomised, single-blind, pilot trial. Lancet Neurol. 16, 691-700 https://doi.org/10.1016/S1474-4422(17)30166-7

Oliviero A, Mordillo-Mateos L, Arias P, Panyavin I, Foffani G, Aguilar J (2011): Transcranial static magnetic field stimulation of the human motor cortex. J. Physiol. 589, 4949-4958 https://doi.org/10.1113/jphysiol.2011.211953

Palm U, Keeser T, Hasan A, Kupka MJ, Blautzik J, Sarubin N, Kaymakanova F, Unger I, Falkai P, Meindl F, Ertl-Wagner B, Padberg F (2016): Prefrontal transcranial direct current stimulation for treatment of schizophrenia with predominant negative symptoms: a double-blind, sham-controlled proof-ofconcept study. Schizophr. Bull. 42, 1253-1261 https://doi.org/10.1093/schbul/sbw041

Paulus W (2011a):. Transcranial static magnetic field stimulation in man: making things as simple as possible? J. Physiol. 589, 5917-5918 https://doi.org/10.1113/jphysiol.2011.221655

Paulus W (2011b): Transcranial electrical stimulation (tES - tDCS; tRNS, tACS): methods. Neuropsychol. Rehabil. 21, 602-617 https://doi.org/10.1080/09602011.2011.557292

Peng W, Tang D (2016): Pain related cortical oscillations: methodological advances and potential applications. Front. Comput. Neurosci. 10, 9 https://doi.org/10.3389/fncom.2016.00009

Pereira EA, Green AL, Nandi D, Aziz TZ (2007): Deep brain stimulation: indications and evidence. Expert Rev. Med. Devices 4, 591-603 https://doi.org/10.1586/17434440.4.5.591

Pereira EA, Green AL, Aziz TZ (2013): Deep brain stimulation for pain. Handb. Clin. Neurol. 116, 277-294 https://doi.org/10.1016/B978-0-444-53497-2.00023-1

Pereira Junior BS, Tortella G, Lafer B, Nunes P, Bense-or IM, Lotufo PA, Machado-Vieira R, Brunoni AR (2015): The bipolar depression electrical treatment trial (better): design, rationale, and objectives of a randomized, sham-controlled trial and data from the pilot study phase. Neural. Plast. 2015, 684025 https://doi.org/10.1155/2015/684025

Pergolizzi J, Böger RH, Budd K, Dahan A, Erdine S, Hans G, Kress HG, Langford R, Likar R, Raffa RB, Sacerdote P (2008): Opioids and the management of chronic severe pain in the elderly: consensus statement of an International Expert Panel with focus on the six clinically most often used World Health Organization Step III opioids (buprenorphine, fentanyl, hydromorphone, methadone, morphine, oxycodone). Pain Pract. 8, 287-313 https://doi.org/10.1111/j.1533-2500.2008.00204.x

Peterchev AV, Wagner AT, Miranda PC, Nitsche MA, Paulus W, Lisanby SH, Pascual-Leone A, Bikson M (2012): Fundamentals of transcranial electric and magnetic stimulation dose: Definition, selection, and reporting practices. Brain Stimulation 5, 435-453 https://doi.org/10.1016/j.brs.2011.10.001

Peters ML (2015): Emotional and cognitive influences on pain experience. Mod. Trends Pharmacopsychiatry 30,138-152 
https://doi.org/10.1159/000435938

Pogosyan A, Gaynor LD, Eusebio A, Brown P (2009): Boosting cortical activity at Beta-band frequencies slows movement in humans. Curr Biol. 13, 1637-1641 https://doi.org/10.1016/j.cub.2009.07.074

Politi E, Fauci E, Santoro A, Smeraldi E (2008): Daily sessions of transcranial magnetic stimulation to the left prefrontal cortex gradually reduce cocaine craving. Am. J. Addict. 17, $345-346$ https://doi.org/10.1080/10550490802139283

Prikryl R, Ustohal L, Prikrylova KH, Kasparek T, Venclikova S, Vrzalova M (2013): A detailed analysis of the effect of repetitive transcranial magnetic stimulation on negative symptoms of schizophrenia: a double-blind trial. Schizophr. Res. 149, $167-173$ https://doi.org/10.1016/j.schres.2013.06.015

Priori A, Berardelli A, Rona S, Accornero N, Manfredi M (1998): Polarization of the human motor cortex through the scalp. Neuroreport 9, 2257-2260 https://doi.org/10.1097/00001756-199807130-00020

Radnovich R1, Chapman CR, Gudin JA, Panchal SJ, Webster LR, Pergolizzi JV Jr. (2014): Acute pain: effective management requires comprehensive assessment. Postgrad. Med. 126, 59-72 https://doi.org/10.3810/pgm.2014.07.2784

Radzievsky AA, Gordiienko OV, Szabo I, Alekseev SI, Ziskin MC (2004): Millimeter wave-induced suppression of B16 F10 melanoma growth in mice: involvement of endogenous opioids. Bioelectromagnetics 25, 466-473 https://doi.org/10.1002/bem.20018

Rakel BA, Zimmerman MB, Geasland K, Embree J, Clark CR, Noiseux NO, Callaghan JJ, Herr K, Walsh D, Sluka KA (2014): Transcutaneous electrical nerve stimulation for the control of pain during rehabilitation after total knee arthroplasty: A randomized, blinded, placebo-controlled trial. Pain 155, 2599-22611 https://doi.org/10.1016/j.pain.2014.09.025

Reddi D (1998): An introduction to pain pathways and mechanisms. In: Churchill's Pocket Book of Pain. First edition. (Eds: Stannard C, Booth S), Churchill Livingstone, Edinburgh Richardson DE, Akil H (1977a): Pain reduction by electrical stimulation in man. Part 1: Acute administration in periaqueductal and periventricular sites. J. Neurosurg. 47, 178-183

Richardson DE, Akil H (1977b): Pain reduction by electrical stimulation in man. Part 2: Chronic self-administration in periaqueductal grey matter. J. Neurosurg. 47, 184-194 https://doi.org/10.3171/jns.1977.47.2.0184

Robertson JA, Juen N, Théberge J, Weller J, Drost DJ, Prato FS, Thomas AW (2010): Evidence for a dose-dependent effect of pulsed magnetic fields on pain processing. Neurosci. Lett. 482, 160-162 https://doi.org/10.1016/j.neulet.2010.07.024

Rocha CS, Lanferdini FJ, Kolberg C, Silva MF, Vaz MA, Partata WA, Zaro MA (2012): Interferential therapy effect on mechanical pain threshold and isometric torque after delayed onset muscle soreness induction in human hamstrings. J. Sports Sci. 30, 733-742 https://doi.org/10.1080/02640414.2012.672025

Rokyta R, Fricová J (2012): Neurostimulation methods in the treatment of chronic pain. Physiol. Res. 61 (Suppl 2), 23-31
Russo JF, Sheth SA (2015): Deep brain stimulation of the dorsal anterior cingulate cortex for the treatment of chronic neuropathic pain. Neurosurg. Focus 38, E11 https://doi.org/10.3171/2015.3.FOCUS1543

Russo C, Carneiro M, Bolognini N, Fregni F (2017): Safety review of transcranial direct current stimulation in stroke tdcs in stroke: safety review. Neuromodulation 20, 215-222 https://doi.org/10.1111/ner.12574

Sabino GS, Santos CM, Francischi JN, de Resende MA (2008): Release of endogenous opioids following transcutaneous electric nerve stimulation in an experimental model of acute inflammatory pain. J. Pain 9, 157-163 https://doi.org/10.1016/j.jpain.2007.09.003

Saturnino GB, Madsen KH, Siebner HR, Thielscher A (2017): How to target inter-regional phase synchronization with dual-site transcranial alternating current stimulation. NeuroImage $163,68-80$ https://doi.org/10.1016/j.neuroimage.2017.09.024

Schabrun SM, Lamont RM, Brauer SG (2016): Transcranial direct current stimulation to enhance dual-task gait training in parkinson's disease: a pilot rct. PLoS One 11, e0158497 https://doi.org/10.1371/journal.pone.0158497

Schjetnan AGP, Faraji J, Metz GA, Tatsuno M, Luczak A (2013): Transcranial direct current stimulation in stroke rehabilitation: a review of recent advancements. Stroke Res. Treat. 2013, 170256

Serpell M (2006): Anatomy, physiology and pharmacology of pain. Surgery 24, 350-353

https://doi.org/10.1053/j.mpsur.2006.08.002

Serra J, Collado A, Solà R, Antonelli F, Torres X, Salgueiro M, Quiles C, Bostock H (2014): Hyperexcitable C nociceptors in fibromyalgia. Ann Neurol. 75, 196-208 https://doi.org/10.1002/ana.24065

Schaible HG, Ebersberger A, Natura G (2011): Update on peripheral mechanisms of pain: beyond prostaglandins and cytokines. Arthritis Res Ther. 13, 210 https://doi.org/10.1186/ar3305

Shealy CN, Mortimer JT, Resnick J (1967): Electrical inhibition of pain by stimulation of the dorsal columns: preliminary reports. J. Int. Anesth. Res. Soc. 46, 489-491 https://doi.org/10.1213/00000539-196707000-00025

Shen Y, Cao XY, Tan T, Shan CL, Wang YJ, Pan JB, He H, Yuan TF (2016): 10-Hz Repetitive transcranial magnetic stimulation of the left dorsolateral prefrontal cortex reduces heroin cue craving in long-term addicts. Biol. Psychiatry 80, 13-14 https://doi.org/10.1016/j.biopsych.2016.02.006

Shen Y, Cao XY, Shan CL, Dai WJ, Yuan TF (2017): Heroin addiction impairs human cortical plasticity. Biol. Psychiatry 81, 49-50 https://doi.org/10.1016/j.biopsych.2016.06.013

Shupak NM, McKay JC, Nielson WR, Rollman GB, Prato FS, Thomas AW (2006): Exposure to a specific pulsed low-frequency magnetic field: a double-blindplacebo-controlled study of effects on pain ratings in rheumatoid arthritis and fibromyalgia patients. Pain Res. Manag. 11, 85-90 https://doi.org/10.1155/2006/842162

Sims-Williams H, Matthews J, Talbot P, Love-Jones S, Brooks J, Patel NK, Pickering AE (2017): Deep brain stimulation of 
periaqueductal gray releases endogenous opioids in humans. Neuroimage 146, 833-842

https://doi.org/10.1016/j.neuroimage.2016.08.038

Son BC, Choi JG, Ha SW (2018): cerebrospinal fluid egress from the quadripolar deep brain stimulation electrode for anterior nucleus of the thalamus for refractory epilepsy. Asian J. Neurosurg. 13, 407-410

https://doi.org/10.4103/ajns.AJNS_148_16

Souto G, Borges IC, Goes BT, de Mendonça ME, Gonçalves RG, Garcia LB, Sá KN, Coutinho MR, Galvão-Castro B, Fregni F, Baptista AF (2014): Effects of tDCS-induced motor cortex modulation on pain in HTLV-1: a blind randomized clinical trial. Clin. J. Pain 30, 809-815 https://doi.org/10.1097/AJP.0000000000000037

Stein C, Hassan AHS, Przewlocki R, Gramsch C, Peter K, Herz A (1990): Opioids from immunocytes interact with receptors on sensory nerves to inhibit hyperalgesia in inflammation. PNAS 87, 5935-5939 https://doi.org/10.1073/pnas.87.15.5935

Stein C, Schafer M, Machelska H (2003): Attacking pain at its source: new perspectives on opioids. Nat. Med. 9, 1003-1008 https://doi.org/10.1038/nm908

Takeda N, Horisawa S, Taira T, Kawamata T (2018): Radiofrequency lesioning through deep brain stimulation electrodes in patients with generalized dystonia. World Neurosurg. 115, 220-224 https://doi.org/10.1016/j.wneu.2018.04.055

Teismann H, Wollbrink A, Okamoto H, Schlaug G, Rudack C, Pantev C (2014): Combining transcranial direct current stimulation and tailor-made notched music training to decrease tinnitus-related distress - a pilot study. PLoS One 9, e89904 https://doi.org/10.1371/journal.pone.0089904

Terney D, Chaieb L, Moliadze V, Antal A, Paulus W (2008): Increasing human brain excitability by transcranial high-frequency random noise stimulation. J. Neurosci. 28, 14147-14155 https://doi.org/10.1523/JNEUROSCI.4248-08.2008

Thomas AW, White KP, Drost DJ, Cook CM, Prato FS (2001): A comparison of rheumatoid arthritis and fibromyalgia patients and healthy controls exposed to a pulsed (200 microT): magnetic field: effects on normal standing balance. Neurosci Lett. 309, 17-20 https://doi.org/10.1016/S0304-3940(01)02009-2

Thomas AW, Graham K, Prato FS, McKay J, Forster PM, Moulin DE, Chari S (2007): A randomized, double-blind, placebo-controlled clinical trial using a low-frequency magnetic field in the treatment of musculoskeletal chronic pain. Pain. Res. Manag. 12, 249-258 https://doi.org/10.1155/2007/626072

Tortella G, Casati R, Aparicio LVM, Mantovani A, Senço N, D‘Urso G, Brunelin J, Guarienti F, Selingardi PML, Muszkat D, et al. (2015): Transcranial direct current stimulation in psychiatric disorders. World J. Psychiatry 5, 88-102 https://doi.org/10.5498/wjp.v5.i1.88

Valle A, Roizenblatt S, Botte S, Zaghi S, Riberto M, Tufik S, Boggio PS, Fregni F (2010): Efficacy of anodal transcranial direct current stimulation (tDCS): for the treatment of fibromyalgia: results of a randomized, sham-controlled longitudinal clinical trial. J. Pain Manag. 2, 353-361

Vigod S, Dennis CL, Daskalakis Z, Murphy K, Ray J, Oberlander T, Somerton S, Hussain-Shamsy N, Blumberger D (2014):
Transcranial direct current stimulation (tDCS): for treatment of major depression during pregnancy: study protocol for a pilot randomized controlled trial. Trials 15, 366 https://doi.org/10.1186/1745-6215-15-366

Wagner T, Valero-Cabre A, Pascual-Leone A (2007): Noninvasive human brain stimulation. Annu. Rev. Biomed. Eng. 9, 527-565 https://doi.org/10.1146/annurev.bioeng.9.061206.133100

Walker J, Hutchison P, Ge J, Zhao D, Wang Y, Rothwell PM, Gaziano JM, Chan A, Burn J, Chia J, et al. (2018): Aspirin: 120 years of innovation. A report from the 2017 Scientific Conference of the International Aspirin Foundation, 14 September 2017, Charité, Berlin. Ecancermedicalscience 12, 813 https://doi.org/10.3332/ecancer.2018.813

Walker UA, Uhl M, Weiner SM, Warnatz K, Lange-Nolde A, Dertinger H, Peter HH, Jurenz SA (2006): Analgesic and disease modifying effects of interferential current in psoriatic arthritis. Rheumatol. Int. 10, 904-907 https://doi.org/10.1007/s00296-006-0102-y

Wang Y, Guo L (2016): Nanomaterial-enabled neural stimulation. Front. Neurosci. 10, 69 https://doi.org/10.3389/fnins.2016.00069

Weigel M, Krauss J (2004): Center median parafascicular complex and pain control. Sterotact. Funct. Neurosurg. 82, 115-126 https://doi.org/10.1159/000079843

Winter JO, Gomez N, Korgel BA, Schmidt CE (2005): Quantum dots for electrical stimulation of neural cells. Proc. SPIE 5705, 235-246 https://doi.org/10.1117/12.602363

Winter L, Heitland I, Saryyeva A, Lütjens G, Schwabe K, Heissler HE, Alam M, Kahl KG, Krauss JK (2017): Acute effects of electrical stimulation of the bed nucleus of the stria terminalis/ internal capsule in obsessive-compulsive disorder. World Neurosurg. 111, e471-e477 https://doi.org/10.1016/j.wneu.2017.12.084

Wolff RF, Aune D, Truyers C, Hernandez AV, Misso K, Riemsma R, Kleijnen J (2012): Systematic review of efficacy and safety of buprenorphine versus fentanyl or morphine in patients with chronic moderate to severe pain. Curr. Med. Res. Opin. 28, 833-845 https://doi.org/10.1185/03007995.2012.678938

Yamgoue Y, Pralong E, Levivier M, Bloch J (2016): Deep brain stimulation of the ventroposteromedial (VPM): thalamus 10 years after VPM thalamotomy to treat a recurrent facial pain. Stereotact. Funct. Neurosurg. 94, 118-122 https://doi.org/10.1159/000444762

Yue K, Guduru R, Hong J, Liang P, Nair M, Khizroev S (2012): Magneto-electric nano-particles for non-invasive brain stimulation. PLoS One 7, e44040 https://doi.org/10.1371/journal.pone.0044040

Zaehle T, Rach S, Herrmann CS (2010): Transcranial alternating current stimulation enhances individual alpha activity in human EEG. PLoS One 5, e13766 https://doi.org/10.1371/journal.pone.0013766

Ziskin MC (2013): Millimeter waves: acoustic and electromagnetic. Bioelectromagnetics 34, 3-14 https://doi.org/10.1002/bem.21750

Received: February 14, 2018

Final version accepted: July 11, 2018 